\title{
STEERING A GREEN, HEALTHY, AND INCLUSIVE RECOVERY THROUGH TRANSPORT
}

TRAVIS FRIED, BENJAMIN WELLE, AND SERGIO AVELLEDA

\section{EXECUTIVE SUMMARY}

\section{Highlights}

The pandemic and resulting economic fallout have upended means of mobility, such as public transport and air travel.

- This report evaluates how countries, cities, and companies have allocated funds, directed policies, or launched actions that impact the transport sector. It provides evidence of how these interventions could shape long-term economic recovery that addresses climate, health, safety, and equity goals.

- This study analyzes roughly US $\$ 298$ billion in global stimulus funds committed to the transport sector between March 2020 and February 2021. Of these funds, roughly 44 percent have gone to subsectors with positive implications for climate and sustainability goals.

We are at a critical moment to steer national investments, local and country-level regulations, and private-sector commitments toward sustainable transport.

This paper identifies several intersectional opportunities and explores five key opportunities and action areas for transport decarbonization and public-private participation for countries, cities, and companies. These areas are public transport, walking and bicycling, vehicle electrification, rail, and research and development (R\&D). Actions in these areas can help decarbonize transport while creating jobs, increasing equity, improving road safety, and reducing air pollution.

\section{CONTENTS}

Executive Summary ..................................

Introduction ....................................... 6

COVID-19 Impacts on Transport .................... 9

Ushering in a Green Recovery

through Sustainable Mobility ........................ 11

Transport-Related Stimulus Spending

and Policy Responses ............................. 15

Key Opportunities................................. 21

Raising Ambition for COP26 ........................25

Conclusion: A Better "New Normal" for Transport? ... 27

Appendix A: Extended Methodology

and Exploratory Analysis .........................28 28

Endnotes........................................... 33

References ......................................... 33

Acknowledgments................................ 40

Working Papers contain preliminary research, analysis, findings, and recommendations. They are circulated to stimulate timely discussion and critical feedback, and to influence ongoing debate on emerging issues.

Suggested Citation: Fried, T., B. Welle, and S. Avelleda. 2021. "Steering a Green, Healthy, and Inclusive Recovery through Transport" Working Paper. Washington, DC: World Resources Institute. Available online at doi.org/10.46830/wriwp.20.00134. 


\section{Context}

COVID-19 dramatically upended mobility. Public transport ridership and revenues have collapsed, forcing many agencies to cut services and raise fares (Welle and Avelleda 2020). In low-income regions, economic shutdowns likely will worsen poverty and deepen inequity of access to core opportunities for years to come. There is mounting concern that people will increasingly opt for private vehicles, which would have devasting consequences for our health, safety, and the climate.

There is a green lining, however. Hundreds of cities, from Lima to Paris to Kampala, are adding new bicycle and walking facilities, while bicycles and electric bicycles are seeing record sales. Capitalizing on this "active transport" renaissance could curb growing car usage; accommodate healthier, cleaner, and more inclusive modes of travel; and invigorate local businesses that rely on foot traffic. Transport companies have ramped up climate ambitions too. Major transport companies, from e-commerce giants to ride-hail providers and automobile manufacturers, are setting targets to drastically cut emissions, procure electric vehicles (EVs), and phase out internal combustion engines.

Between March 2020 and February 2021, national governments committed an unprecedented $\$ 298$ billion in economic stimulus to transport-related sectors (see Figure ES-1). Although less than half of these funds have gone to sustainable transport, major national investments in stabilizing public transport services, new rail lines and services, active transport infrastructure, accelerated $\mathrm{EV}$ and zero-emission fuel adoption, and environmentally minded aviation-sector bailouts (e.g., funding clean R\&D for sustainable aviation fuels) present renewed opportunities for countries, cities, and companies to decarbonize transport.

\section{About This Paper}

This paper takes an in-depth look at how cities, countries, and companies are responding to today's mobility upheaval, and, in doing so, driving decisions for tomorrow. More specifically, it reviews recovery-related stimulus and policies within the transport sector and offers long-term considerations for decision-makers to shape an economic recovery that links climate, equity, health, and safety. Commissioned by the Transport Decarbonisation Alliance (TDA), which is chaired by Netherlands environment minister Stientje van Veldhoven, this working paper contributes to the TDA's framework of uniting country, city/region, and company (3C) action to decarbonize passenger and freight transportation (TDA 2018). In addition, the 26th United Nations Conference of the Parties (COP26) in November 2021 will increase the need to align stimulus with the raised ambition sought in countries' nationally determined contributions (NDCs) (Fransen et al. 2019).

\section{Opportunities to Steer Transport toward Green Recovery}

This paper identifies several intersectional opportunities and explores five major action areas for transport decarbonization and public-private participation among 3C stakeholders (see Table ES-1). Doing so would not only help decarbonize the sector faster but also create jobs, ensure equitable access to economic opportunities and health care, improve road safety, and reduce deadly air pollution.

\section{Opportunity \#1: Stabilize and reimagine public transport}

Finding: Mass transit investments likely have high direct and indirect employment multiplying effects when compared to car-oriented development projects, like highway building. Moreover, investing in public transport increases equal access to jobs and services, improves road safety, reinforces smart urban growth, and limits carbon emissions.

Action areas: Local and national governments must stabilize public transport operations and liquidity through emergency funds. However, strengthening services and capturing ridership for the long run will require transit stakeholders to reimagine governance, finance, priority infrastructure, data and modal integration, and publicprivate partnerships, among other areas.

\section{Opportunity \#2: Double down on active transport}

Finding: Compact and walkable neighborhoods and cities have stronger economies and are less emissions-intensive, safer, and healthier. As with mass transit, studies observe that active mobility infrastructure investments likely create more direct and indirect jobs per dollar spent than road-only projects and have relatively high potential to create jobs across other green sectors. 
Action areas: With demand and advocacy for active transport infrastructure at an all-time high, cities must expand walking and bicycling facilities and make them permanent, in addition to exploring opportunities to integrate micromobility services, such as bikeshare. Countries must increase funding and improve governance at a national level. In some instances they can offer rebates and incentives for the purchase of electric and pedal bicycles and equipment. Meanwhile, companies should promote sustainable commutes through incentive programs.

\section{Opportunity \#3: Accelerate electrification and efficiency}

Finding: Raising vehicle fuel efficiency and accelerating EV adoption play a critical role in mitigating climate emissions and improving air quality and can lead to job growth, primarily in the installation of public charging infrastructure. To achieve net-zero emissions, EV adoption and production must parallel a transition to renewable energy generation and smarter vehicle-grid integration.

Action areas: Public policy incentives and mandates are important to accelerate private sector EV investments and procurement. However, policy actions must harmonize across the $3 \mathrm{Cs}$. Installing public charging infrastructure or instituting zero-emission zones, for instance, are great opportunities for cross-sector collaboration. Governments and private operators should also prioritize the decarbonization of commercial vehicle and municipal fleets, including buses, waste collection and emergency vehicles, and freight carriers.

\section{Opportunity \#4: Shift people and goods to rail}

Finding: Rail is and historically has been a prominent investment item in stimulus packages. Rail investments can have long-term value, both environmental and economic, when they result in shifts from more energyintensive passenger and freight modes. After ensuring that rail investments have green targets at the outset, they can substitute for other large infrastructure investments like highway building.

Action areas: Rail investments under consideration should prioritize electrifying current assets and bringing passenger and goods travel away from more energy-inten- sive modes, especially long-distance car and truck trips and short-distance air. Investors should leverage opportunities for public-private participation, such as through rail and railcar-sharing schemes, franchise contracts, and the installation of amenities (e.g., Wi-Fi).

\section{Opportunity \#5: Fund clean R\&D and a just transition}

Finding: Stimulus packages offer an opportunity to fund research and development into emerging zero-emission fuels and technologies, which will prove essential to decarbonizing harder-to-abate sectors, such as aviation and shipping. Ushering in new zero-emission industries can help create jobs and improve livelihoods, but only through a just transition that prioritizes workforce training and education.

Action areas: The $3 \mathrm{Cs}$ must set clear targets and invest in clean R\&D to increase market adoptability and commercial demand for zero-emission fuels. Since jobs in zero-emission industries come at the expense of jobs in fossil fuel and carbon-intensive industries, governments, academic institutions, and companies must institute comprehensive measures for vocational training to improve skill transferability, ensure social inclusion, and strengthen livelihoods. 
1. How much did global governments spend on transport in their stimulus packages? WRI analyzed $\$ 618$ billion in energy-related stimulus, or 266 policies in 24 countries. Of these funds, $48 \%$ went to transport ( 2298 billion), accounting for only $0.35 \%$ of global GDP in 2020 .

National recovery-related spending as percent of GDP

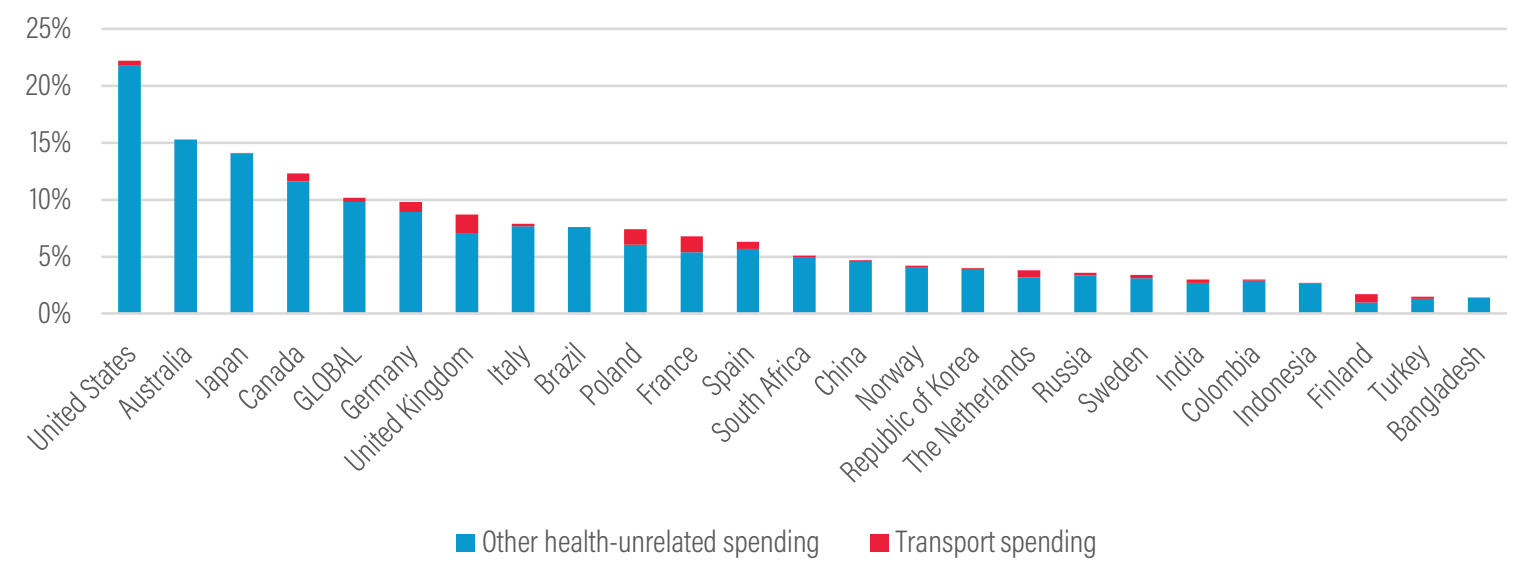

Note: GDP = gross domestic product.

Source: WRI analysis via Energy Policy Tracker (2021); IMF (2021); OECD (2021).

2. How "green" was transport spending? Only $44 \%$ ( $\$ 130$ billion) of transport funds went to transport subsectors with positive environmental implications. The remaining "gray" funds mostly included unconditional bailouts to aviation and car manufacturing industries as well as roadbuilding programs; however, some fossil fuel policies were hard to quantify. For example, 10 out of 24 countries analyzed had policies that repealed or deferred internal combustion engine vehicle tax or emission standards. Here is how countries spent green transport investments:

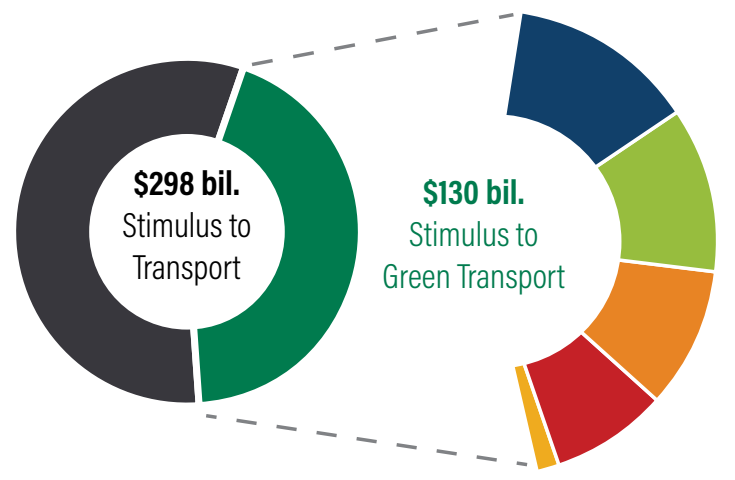

30\% Public transport stabilization

$26 \%$ Rail construction and services

$4 \quad 22 \%$ Electric vehicles and zeroemission fuels

₹ $18 \%$ Green aviation/maritime support

$4 \%$ Active transport

\section{Did transport companies regress or progress on climate commitments? Despite economic hardship, transport companies appear to have committed to more climate action. Since 2015, 1,274 companies have announced climate targets and commitments in accordance with the Paris Agreement. Of these companies, 239 announced targets since January 2021 alone. Roughly $7 \%$ were in transport-related industries.}

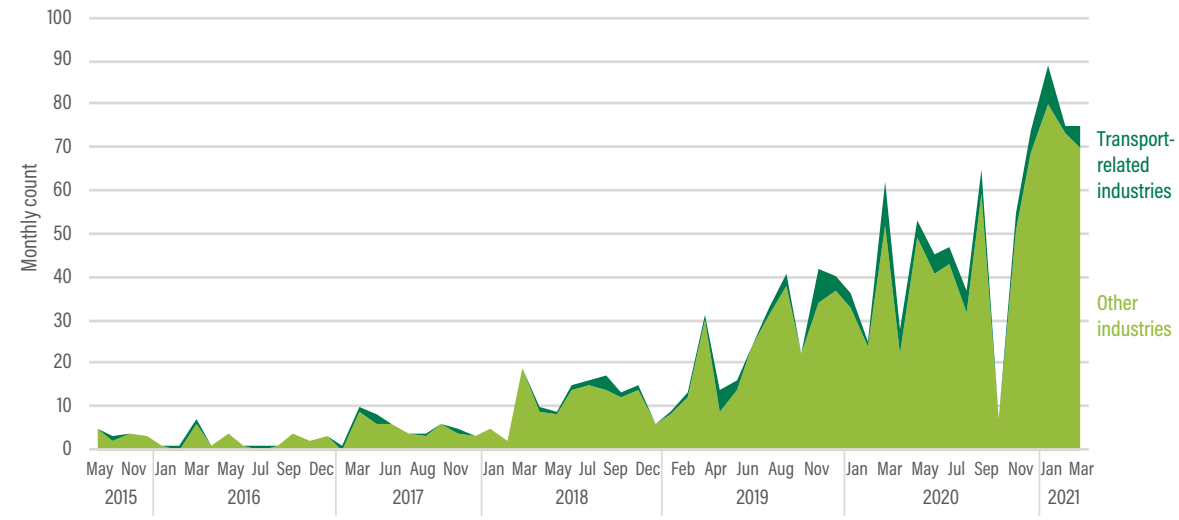

Source: SBTi (2021). 
Table ES-1 | Key action areas and levels of involvement for countries, cities, and companies

\begin{tabular}{|c|c|c|c|c|}
\hline & KEY ACTION AREAS & COUNTRIES & CITIES & COMPANIES \\
\hline & $\begin{array}{l}\text { Avoid the need for } \\
\text { motorized travel }\end{array}$ & $\begin{array}{l}\text { Avoid building new urban highways } \\
\text { Carbon pricing and driving disincentive } \\
\text { mechanisms } \\
\text { Fund programs supporting sustainable } \\
\text { travel behaviors }\end{array}$ & $\begin{array}{l}\text { Compact and connected development; } \\
\text { "15 Minute City" } \\
\text { Parking policy reform and street } \\
\text { management } \\
\text { Transit-oriented development }\end{array}$ & $\begin{array}{l}\text { When possible, implement work-from- } \\
\text { home initiatives } \\
\text { Reduce need for business air travel }\end{array}$ \\
\hline 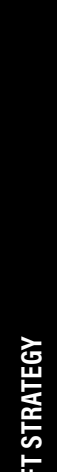 & $\begin{array}{l}\text { Stabilize and } \\
\text { reimagine public } \\
\text { transport }\end{array}$ & $\begin{array}{l}\text { Short-term fiscal support to stabilize } \\
\text { operating expenditures, worker } \\
\text { livelihoods, and rider prophylaxis } \\
\text { Long-term reallocation of funds } \\
\text { to increase development of public } \\
\text { transport at national level }\end{array}$ & $\begin{array}{l}\text { Develop bus-priority infrastructure } \\
\text { Expand public finance instruments to } \\
\text { increase public transport investments } \\
\text { and decrease farebox reliance (e.g., } \\
\text { congestion charge, carbon/fuel tax) } \\
\text { Explore digital applications and } \\
\text { Intelligent Transportation Systems (ITS) } \\
\text { to improve and optimize services (e.g., } \\
\text { digital route rationalization, cashless } \\
\text { payment, passenger information } \\
\text { systems) }\end{array}$ & $\begin{array}{l}\text { Public-private partnerships, data } \\
\text { sharing, and franchise agreements } \\
\text { between public and private transport } \\
\text { operators to expand multimodal } \\
\text { services }\end{array}$ \\
\hline 풀 & $\begin{array}{l}\text { Double down on } \\
\text { active transport }\end{array}$ & $\begin{array}{l}\text { National allocation of funds to active } \\
\text { transport infrastructure and incentive } \\
\text { schemes (e.g., electric bike rebates } \\
\text { and/or tax exemptions) } \\
\text { Institute active transport planning and } \\
\text { governance at national level }\end{array}$ & $\begin{array}{l}\text { Expand pedestrian facilities and } \\
\text { protected bicycle infrastructure } \\
\text { Implement "Safe Systems Approach" to } \\
\text { improve road safety for vulnerable road } \\
\text { users (e.g., lower speed limits, narrow } \\
\text { and protected road crossings) } \\
\text { Set ambitious mode share and "Vision } \\
\text { Zero" road safety targets }\end{array}$ & $\begin{array}{l}\text { Cycle-to-work and sustainable } \\
\text { commute initiatives (e.g., bikeshare } \\
\text { membership discounts) } \\
\text { Public-private partnerships, } \\
\text { financing, and data sharing to expand } \\
\text { micromobility services and integrate } \\
\text { them with public transport }\end{array}$ \\
\hline & $\begin{array}{l}\text { Shift people and } \\
\text { goods to rail }\end{array}$ & $\begin{array}{l}\text { Expand and, if needed, electrify } \\
\text { interurban passenger and freight } \\
\text { railroads, services, stations, and } \\
\text { intermodal facilities } \\
\text { Set mode share targets to capture } \\
\text { ridership and goods transport from } \\
\text { long-distance vehicle and domestic } \\
\text { air travel }\end{array}$ & $\begin{array}{l}\text { If relevant, improve existing light rail } \\
\text { and metro transit stations and services }\end{array}$ & $\begin{array}{l}\text { Passenger/commercial rail sharing } \\
\text { agreements } \\
\text { Public-private partnerships, franchise } \\
\text { agreements, investment to extend rail } \\
\text { services } \\
\text { Explore intermodal solutions for freight }\end{array}$ \\
\hline
\end{tabular}




\begin{tabular}{|c|c|c|c|}
\hline KEY ACTION AREAS & COUNTRIES & CITIES & COMPANIES \\
\hline $\begin{array}{l}\text { Accelerate } \\
\text { electrification and } \\
\text { efficiency }\end{array}$ & $\begin{array}{l}\text { Institute robust blend of economic } \\
\text { policies and incentives to accelerate } \\
\text { electric vehicle (EV) adoption } \\
\text { Set and harmonize national fuel- } \\
\text { efficiency regulations, procurement } \\
\text { mandates, carbon pricing mechanisms, } \\
\text { and targets to phase out internal } \\
\text { combustion engines (ICEs) }\end{array}$ & $\begin{array}{l}\text { Set EV procurement and ICE phaseout } \\
\text { targets to electrify municipal fleets } \\
\text { (e.g., waste management, emergency, } \\
\text { and public works vehicles) } \\
\text { Institute low- and zero-emission zones }\end{array}$ & $\begin{array}{l}\text { Set ambitious targets for EV } \\
\text { procurement and ICE phaseout across } \\
\text { manufacturing, passenger services, } \\
\text { and logistics sectors } \\
\text { Leverage public-private partnerships } \\
\text { and investments (e.g., among utility } \\
\text { companies, original equipment } \\
\text { manufacturers, operators, and } \\
\text { regulators) to expand electric bus fleets } \\
\text { and public charging infrastructure } \\
\text { Introduce digital and information } \\
\text { technology services supply chain } \\
\text { solutions to optimize fleet efficiencies }\end{array}$ \\
\hline $\begin{array}{l}\text { Fund clean research } \\
\text { and development } \\
\text { (R\&D) and just } \\
\text { transition }\end{array}$ & $\begin{array}{l}\text { Establish grant programs to encourage } \\
\text { and derisk zero-emission R\&D and } \\
\text { innovation } \\
\text { Institute just transition policy } \\
\text { mechanisms that center } \\
\text { digital transformation, social } \\
\text { entrepreneurialism, and workforce } \\
\text { training programs }\end{array}$ & $\begin{array}{l}\text { Help facilitate partnerships with local } \\
\text { civil society organizations, companies, } \\
\text { and universities to support small } \\
\text { entrepreneurs, digital innovation hubs, } \\
\text { and professional training programs }\end{array}$ & $\begin{array}{l}\text { Explore innovations and pilots to } \\
\text { implement new zero-emission fuels } \\
\text { (e.g., hydrogen fuel cells, sustainable } \\
\text { aviation fuels) } \\
\text { Set pragmatic but ambitious targets } \\
\text { to improve fuel efficiencies and } \\
\text { decarbonize "harder-to-abate" modes, } \\
\text { such as airplanes, shipping vessels, } \\
\text { and heavy-duty freight }\end{array}$ \\
\hline
\end{tabular}

Note: While equally important, not every action mentioned in this table is explored in this paper. This paper focuses on the intersections between ongoing national green recovery programs and nationally determined contributions (NDCs) as they relate to transport, and their synergies with city policy and company action. Colors: Dark green = high involvement; light green = medium; yellow = low.

Source: WRI authors, adapted from TDA (2018).

\section{INTRODUCTION}

\section{The world faces a devastating convergence of} crises. By the start of 2021, COVID-19 had killed almost 2 million people worldwide while putting over 255 million people out work, mostly in middle- and low-income countries (New York Times 2020; ILO 2021). The economic fallout may have pushed 88-115 million people into extreme poverty in 2020, erasing decades of progress (Mahler et al. 2020). Meanwhile, climate disruption and rising temperatures promise to exacerbate future economic instability and inequity (WEF 2020). Even with sharp cuts to transport and power use due to COVID-19 lockdowns, global carbon dioxide $\left(\mathrm{CO}_{2}\right)$ emissions fell by just 9 percent in 2020 (IEA 2020b; Liu et al. 2020b). Sustaining these emission reductions year after year over the next decade would put us in a position to limit warm- ing to $1.5^{\circ} \mathrm{C}$ (UNEP 2019), but many countries are already seeing emissions rebound as economies reopen and traffic returns to normal (Le Quéré et al. 2020).

\section{Decarbonizing transport can get us to net-zero emissions quicker. Transport is the fastest-growing} $\mathrm{CO}_{2}$ emission source across sectors. As of 2014, transport produced about 23 percent of global energy-related $\mathrm{CO}_{2}$ emissions, the third-largest share next to energy generation and industrial combustion, and 14 percent of total greenhouse gas (GHG) emissions (Sims et al. 2014; SLOCAT 2018). Without direct intervention, transport's share of energy-related $\mathrm{CO}_{2}$ emissions could reach 40 percent by 2030 (ITF 2019). Decarbonizing transport will require a comprehensive avoid-shift-improve framework: avoid unnecessary vehicle travel, shift to more energy- 
efficient and affordable modes-such as walking, bicycling, and public transport-and improve transport's energy efficiency (Dalkmann and Brannigan 2007; Fransen et al. 2019; de Blas et al. 2020).

\section{Some countries, cities, and companies are looking to climate initiatives to jump-start global eco-} nomic recovery. As of February 2021, national governments had committed an unprecedented US $\$ 15$ trillion in fiscal stimulus, more than three times the amount spent during the 2008 Great Financial Recession (Jaeger et al. 2020; IMF 2021). While most funds support health care, businesses, and unemployment benefits, governments have committed 45 percent of funds to energy-related sectors that will have lasting impacts on the environment (Vivid Economics 2021). Transport plays an outsized role in energy-related stimulus spending, albeit with mixed implications for the climate. Assessing a global sample of $\$ 618$ billion in quantified energy-related stimulus com- mitments, 48 percent went to transport-related sectors. Only 44 percent ( $\$ 130$ billion) of transport spending is "green," or has positive environmental impacts (see Figures $1 \mathrm{a}$ and $1 \mathrm{~b})$.

Ensuring that future investments spur a transition toward net-zero emissions is critical not only to realizing global climate goals but also to accelerating an economic and just recovery. C40 estimates that a green recovery could create up to 52 million more jobs than a business-as-usual recovery by 2030 (C40 2020b). Twenty percent of these new green jobs could result from low-carbon transport stimulus. However, while several recent global studies have identified the economic, environmental, and social benefits of a green recovery (IEA 2020a; Engel et al. 2020; OECD 2020a; Hepburn et al. 2020; Gulati et al. 2020; $\mathrm{C} 40$ 2020b), fewer studies have taken a deeper approach to evaluating transport's role in driving that recovery.

Figure 1A | Transport's total share of global energy-related stimulus commitments (US\$ billions)

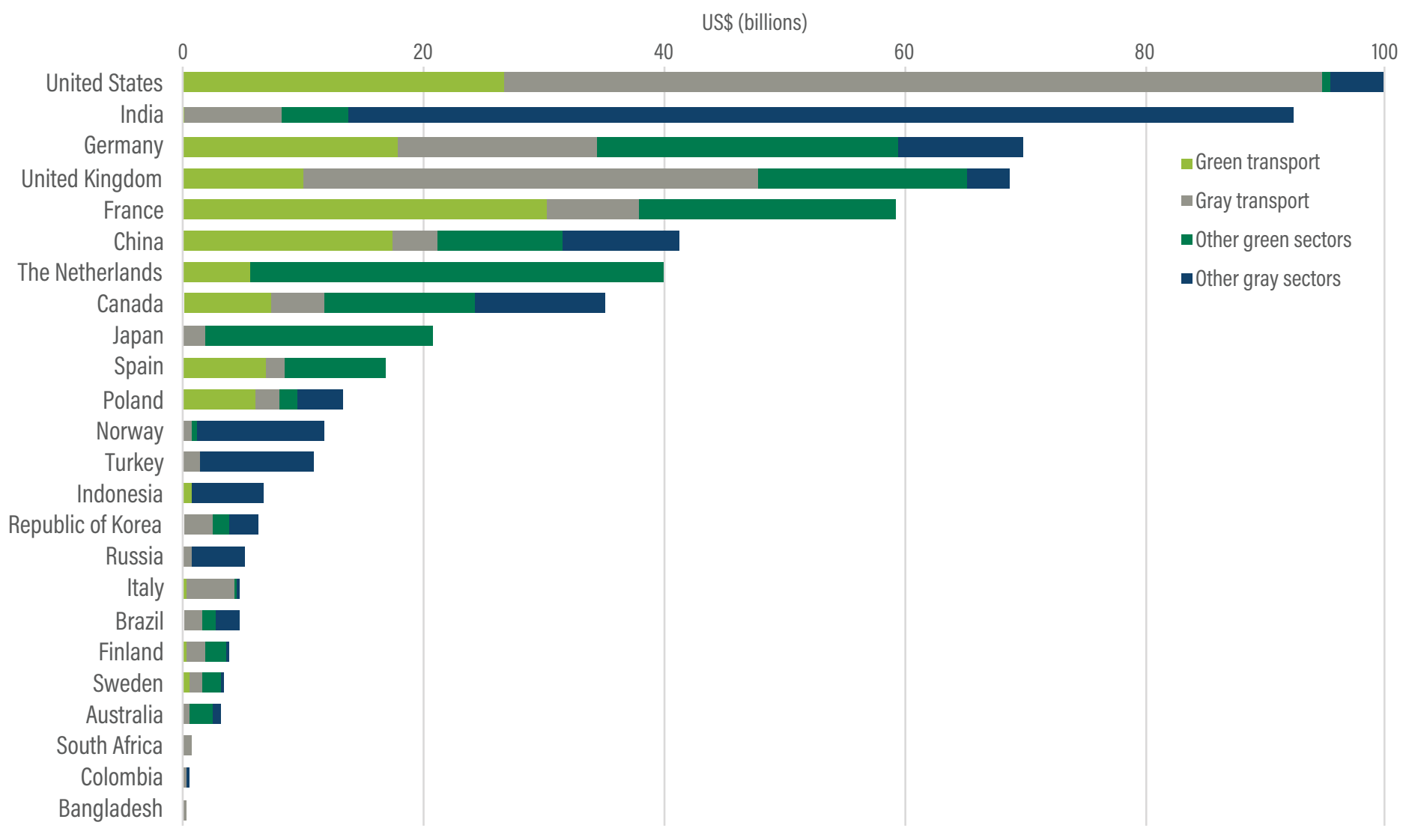




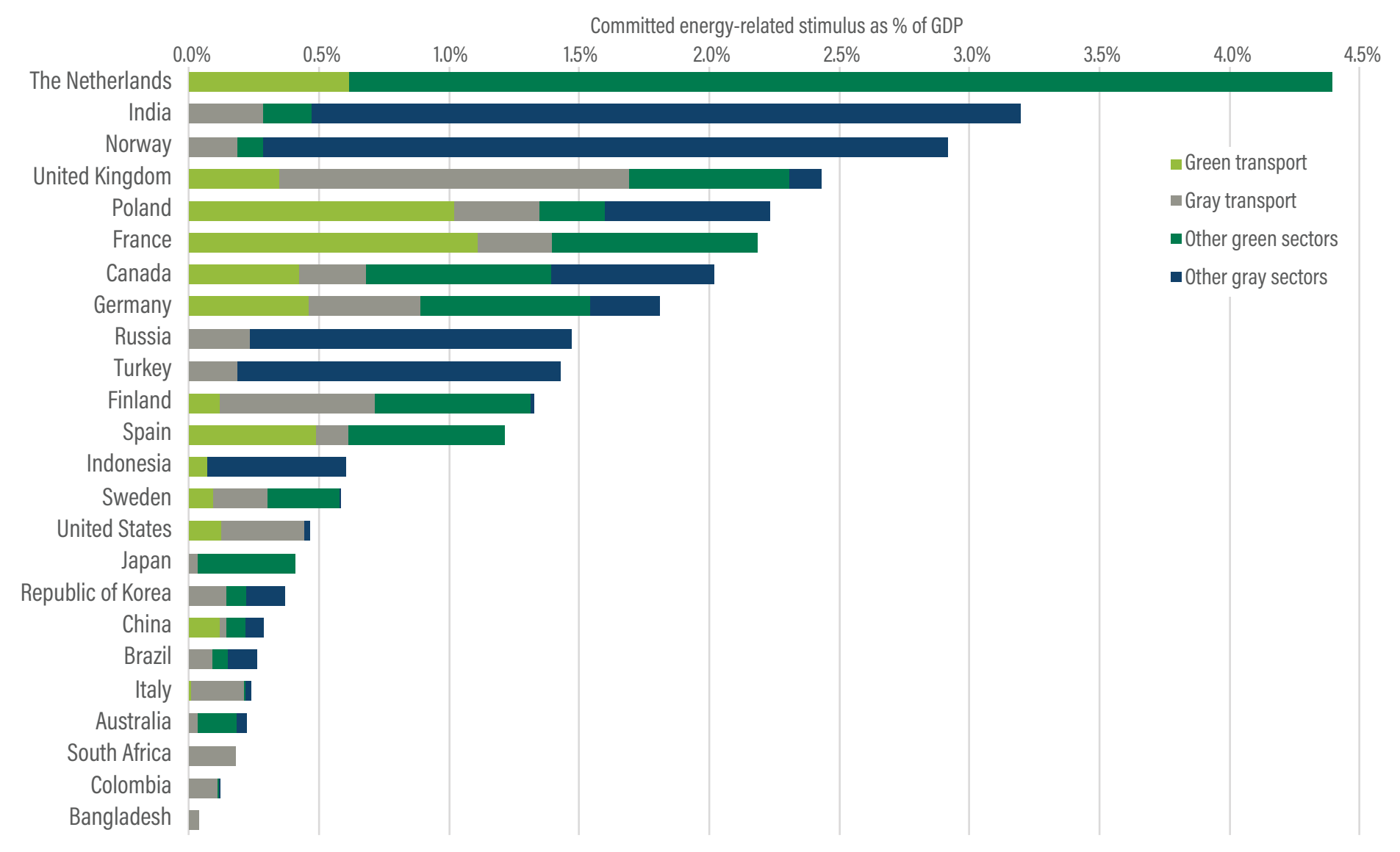

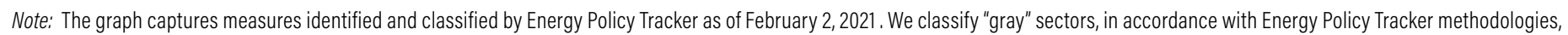

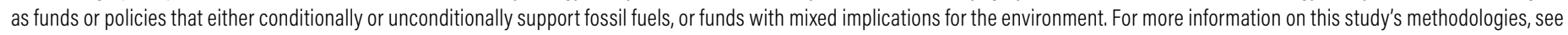
Appendix A. Abbreviation: GDP = gross domestic product.

Source: WRI analysis via Energy Policy Tracker, February 2021.

\section{Methodology}

The purpose of this report is to provide guidance for countries, cities/regions, and companies (the $3 \mathrm{Cs}$ ) to shape an economic recovery through sustainable transport. This report analyzes 266 transport-related stimulus packages tracked by Energy Policy Tracker between March 2020 and February 2021. Energy Policy Tracker is a global database maintained by a consortium of 14 research institutions that tracks fiscal policy responses to the pandemic principally, though not exclusively, in the large G2O countries. While several stimulus trackers exist, we find Energy Policy Tracker to be the most easily accessible and the most complete, with quantified funds and detailed policy descriptions and sources. However, it is important to note that Energy Policy Tracker captures only 3-5 percent of total recovery-related commitments (Energy Policy Tracker 2020). Within the transport sector, responses-including fiscal subsidies, tax relief, interestfree loans, research and development (R\&D) subsidies, city-level regulatory reform, and company-level climate actions (OECD 2020a, 2020b)-are often not captured by the tracker. Since transport decarbonization strategies vary across sectors, geographies, and institutions, this report recommends high-level opportunities and action areas based on an exploratory analysis of current transport-related stimulus and policy-based responses. This paper can help private and public sector decision-makers identify transport interventions that maximize economic benefit, climate mitigation, equity, health, and safety. 
In the conclusion, this report discusses how transportrelated stimulus spending overlaps with raised ambitions of nationally determined contributions (NDCs) and net-zero emission targets from cities and companies, which can help steer a recovery that prioritizes economic growth and bold climate action. Appendix A provides a more detailed discussion of the methodologies used to assess current stimulus and policy responses and identify transport-related opportunity areas that could drive a sustainable recovery.

\section{COVID-19 IIMPACTS ON TRANSPORT}

The pandemic upended transport. National and city governments around the world instituted strict travel restrictions to slow the spread of the virus. Many workplaces and schools moved online and eliminated commutes altogether. However, work-from-home has mostly been a privilege of high-income, formal economies and professions (Berg et al. 2020; Dingel and Neiman 2020; UNICEF 2020).

The most visible effect is the global collapse of passenger transport. International and domestic air travel volumes plummeted 60 percent at the beginning of the pandemic, with losses projected to continue into 2024 (ICAO 2020; IATA 2020). Meanwhile, global public transport ridership plunged from 70 to 90 percent at the outset of the pandemic (Welle and Avelleda 2020). Ridership is still substantially below pre-COVID levels in most major countries (see Figure 2) (Google 2020). As people flee public transport, there is mounting concern that they will increasingly opt for private vehicles (Watts 2020).

However, cities have also seen less car traffic, which has meant clearer skies and less congested streets in some of the world's most densely populated cities (Sung and Monschauer 2020; Bliss et al. 2020). In China, for instance, reduced transport emissions may have prevented over 12,000 deaths between January 2019 and March 2020, greatly outnumbering COVID-related deaths (Chen et al. 2020a).

Electric vehicle (EV) sales have surged as well, despite the overall decline in global vehicle sales. In fact, 2020 ended with record-high global EV sales, over 40 percent higher than the estimate by the International Energy Agency (IEA) for 2019 (Gorner and Paoli 2021). EV sales are up 135 percent from last year in Europe, where many of the $3 \mathrm{Cs}$ began ambitious joint steps to decarbonize transport

Figure 2 | Global change in transit station use from pre-COVID baseline

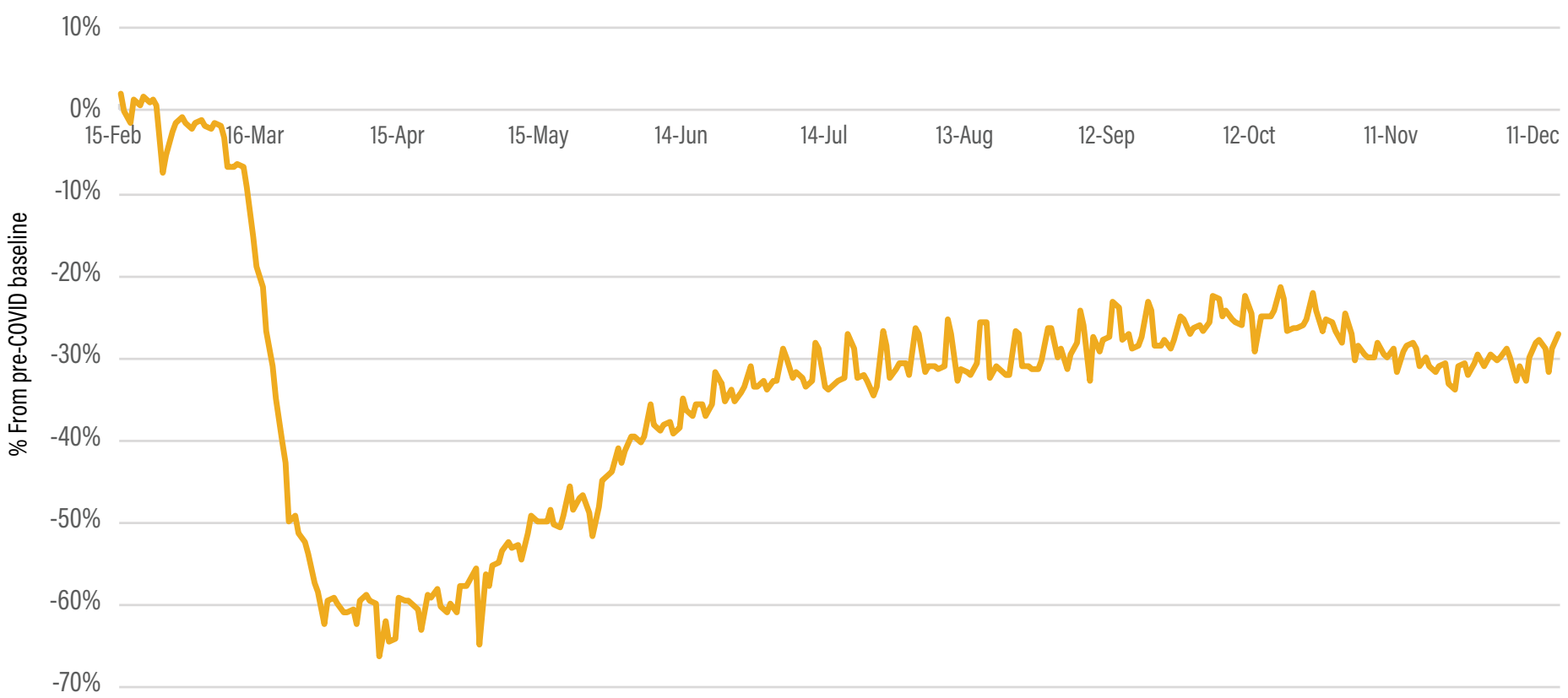

Note: Global average across G20 countries does not include China.

Source: Google (2020). 
prior to COVID, like the United Kingdom's "Road to Zero" and the Netherlands' "Mission Zero" strategies (UK Department for Transport 2018; RVO 2019). Below we highlight the short- and long-term impacts of COVID-19 in the mobility space.

\section{An Active Transport Renaissance}

Less congested streets and the need for outdoor reprieve have put more people in the bicycle saddle than ever before. Bicycle sales and bikeshare rides skyrocketed in New York, London, and Beijing (Bliss et al. 2020; Sung and Monschauer 2020). In Philadelphia, the number of bicyclists on major trails increased close to 500 percent (Tanenbaum 2020). Cities like Paris, Lima, Kampala, and hundreds more closed streets to motor through-traffic, widened sidewalks to provide more space for pedestrians, and added new bicycle lanes (Cities4Health 2020; Reid 2020; Abubaker et al. 2020; ITF 2020a).

\section{Transit Cuts Threaten Equity}

Diminished fare revenues and the increased costs to institute sanitation and physical distancing measures are creating massive deficits. European and Indian public transport agencies anticipated a 2020 loss of $€ 40$ billion ( $\$ 45$ billion) and $\$ 20$ billion, respectively, in fare revenues (Smit et al. 2020; Kharwal and Mukherjee 2020). In the United States, even after disbursing \$25 billion to support public transport in March 2020, agencies collectively needed at least $\$ 32$ billion in additional emergency federal funding to stay afloat (Bellis 2020). In December 2020, the United States committed an additional $\$ 14$ billion to public transport (Wanek-Libman 2020). Should these services not recover, there could be devastating economic consequences for cities. In New York City, proposed subway and bus cuts could lose the region up to 450,000 jobs and $\$ 65$ billion in gross domestic product (GDP) by 2022 (Moss and O’Neill 2020).

Vulnerable communities and low-income workers have felt the impact of service cuts most deeply. At the outset of the lockdown, public transport in many African, Latin American, and Indian cities-where large proportions of the population rely on public transport-halted services or raised fares to make ends meet (World Bank 2020a; UITP 2020; López et al. 2021). Early models from sub-Saharan Africa suggest that an additional 9 percent of the population (80 million people) may have fallen into extreme poverty as a direct result of public transport cuts, among other factors (Teachout and Zipfel 2020). The burden falls on low-income riders, who struggled to afford services even before COVID-19. For instance, in Accra, Ghana, two daily public transport trips cost 60 percent of the daily household income for the bottom fifth of the population (World Bank 2020a). Without an affordable alternative, the poor are left stranded from jobs, health care, and education (Venter et al. 2019).

\section{Transport Companies Respond with Increased Climate Action}

The travel restrictions and economic contraction resulting from the pandemic hurt many transport companies. During the final quarter of 2020, consumer spending on transport in the United States was $\$ 174$ billion lower than in 2019, the second-hardest-hit sector behind food services and accommodations (Mitterling et al. 2020). Some companies responded by pivoting to emergent market trends. Several ride-hail companies have moved into online home and food deliveries, which have soared in countries like the United States and China since March (Meyer 2020; George-Parkin 2020; Isaac et al. 2020). In India, for instance, auto-rickshaw operators have been using empty vehicles to transport goods to clinics, stores, and residences (Thaku et al. 2020).

Additionally, many transport companies have responded with increased climate commitments. Of the 1,274 companies tracked by the Science Based Targets initiative (SBTi), which has tracked company climate targets and commitments since 2015, 239 announced climate action between January and March 2021 alone (SBTi 2021) (see Figure 3). While SBTi classifies only 7 percent of these companies as transport-related, several transport companies have announced major sustainability initiatives since March 2020.

Corporate alliances, such as the Corporate Electric Vehicle Alliance announced in December 2020, have seen major international retail, e-commerce, logistics, and ride-hail companies publicize plans to decarbonize their vehicle fleets (Ceres n.d.). Major automotive manufacturers have pledged long-term ambitions to phase out internal combustion engine (ICE) vehicle manufacturing (TUMI 2021). And between October 2020 and February 2021, business members of the global EV10o initiative collectively deployed 89 percent and 23 percent more passenger and commercial vehicles, respectively, and installed 79 percent more charging stations compared to the year prior (EV100 2021). 


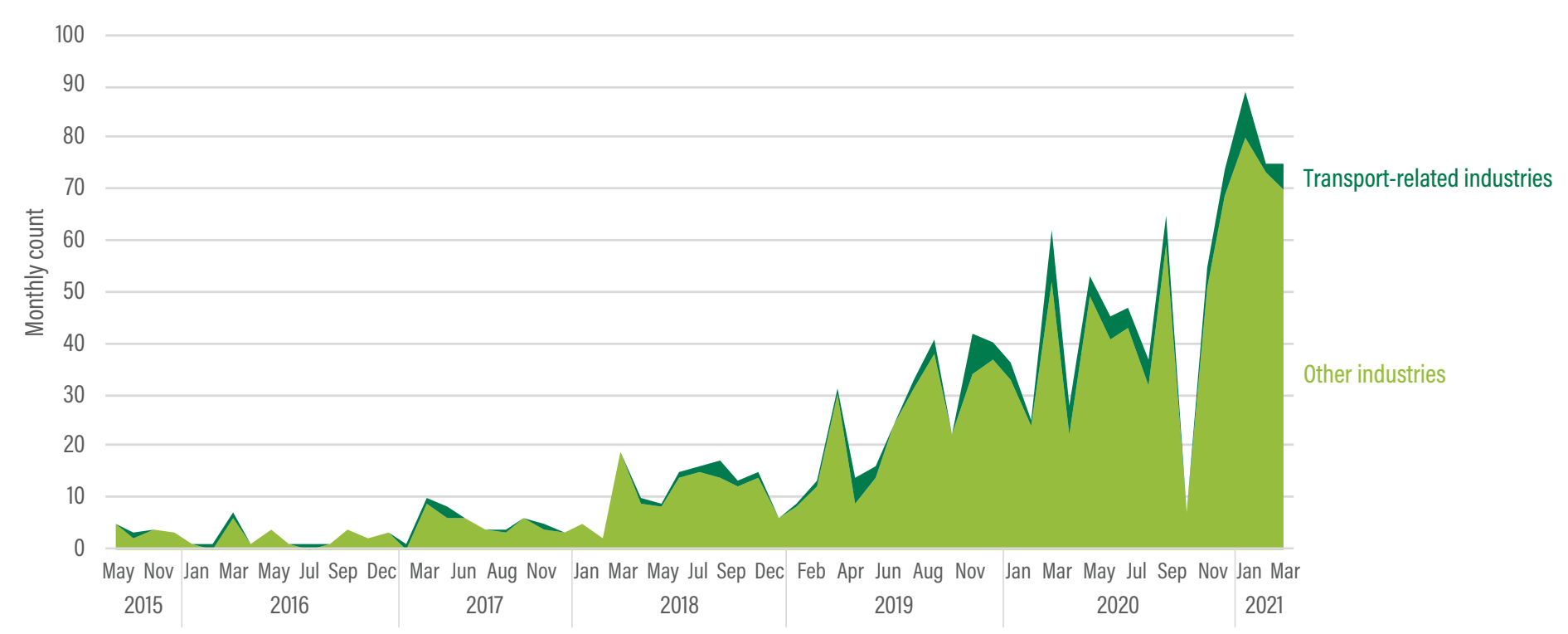

Note: Transport-related industries include air-, water-, and ground-based passenger and commercial transport services as well as automotive manufacturing. Source: SBTi (2021).

\section{USHERING IN A GREEN RECOVERY THROUGH SUSTAINABLE MOBILITY}

\section{Recovery programs present an opportunity to accelerate climate action and rebuild our econ-} omy. Evidence suggests investments into green sectors have outsized economic benefits compared to fossil fuels. During the 2008 Great Financial Recession, South Korea stood out as committing the highest proportion of stimulus funds (69 percent) to green measures, which in large part contributed to the country's above-average rebound in employment and GDP in the years that followed (Jaeger et al. 2020). In Brazil, a green economic recovery could create a net increase of two million jobs and total GDP gain of $\$ 535$ billion by 2030 compared to a business-asusual recovery (Pinheiro et al. 2020). The IEA estimates that investing $\$ 1$ million in building efficiency, clean urban transport, or solar energy creates more than twice as many jobs as investing in coal or gas (IEA 2020a).

Transport decarbonization plays an essential role in an intersectional economic recovery (see Figure 4). Below we examine the role transport decarbonization plays in creating jobs, fighting climate change, and improving health and equal access to opportunities.

\section{Economic Benefits}

While the economic benefit to decarbonizing transport is substantial, net job creation estimates vary across regions and transport subsectors. For instance, evidence suggests the long-term transition to EVs will reduce jobs in the traditional automotive manufacturing sector, since EV assembly is highly automated and requires fewer parts than ICE vehicles (Eisenstein 2019; Bauer et al. 2020). However, an increase in the domestic production of battery cells that power EVs may completely or partially offset jobs lost in automotive manufacturing (Cattaneo 2018; IEA 2020a). Beyond manufacturing jobs, the installation of EV charging infrastructure will generate many electrical utility and construction jobs. Installing EV charging infrastructure creates roughly twice as many jobs as ICE vehicle manufacturing per $\$ 1$ million invested (IEA 2020a).

The largest opportunity for job generation is expanding public and active transport. In the European Union, separate investments in mass transit and active transport infrastructure can create $20-25$ jobs per $€ 1$ million $(\$ 1.2$ 


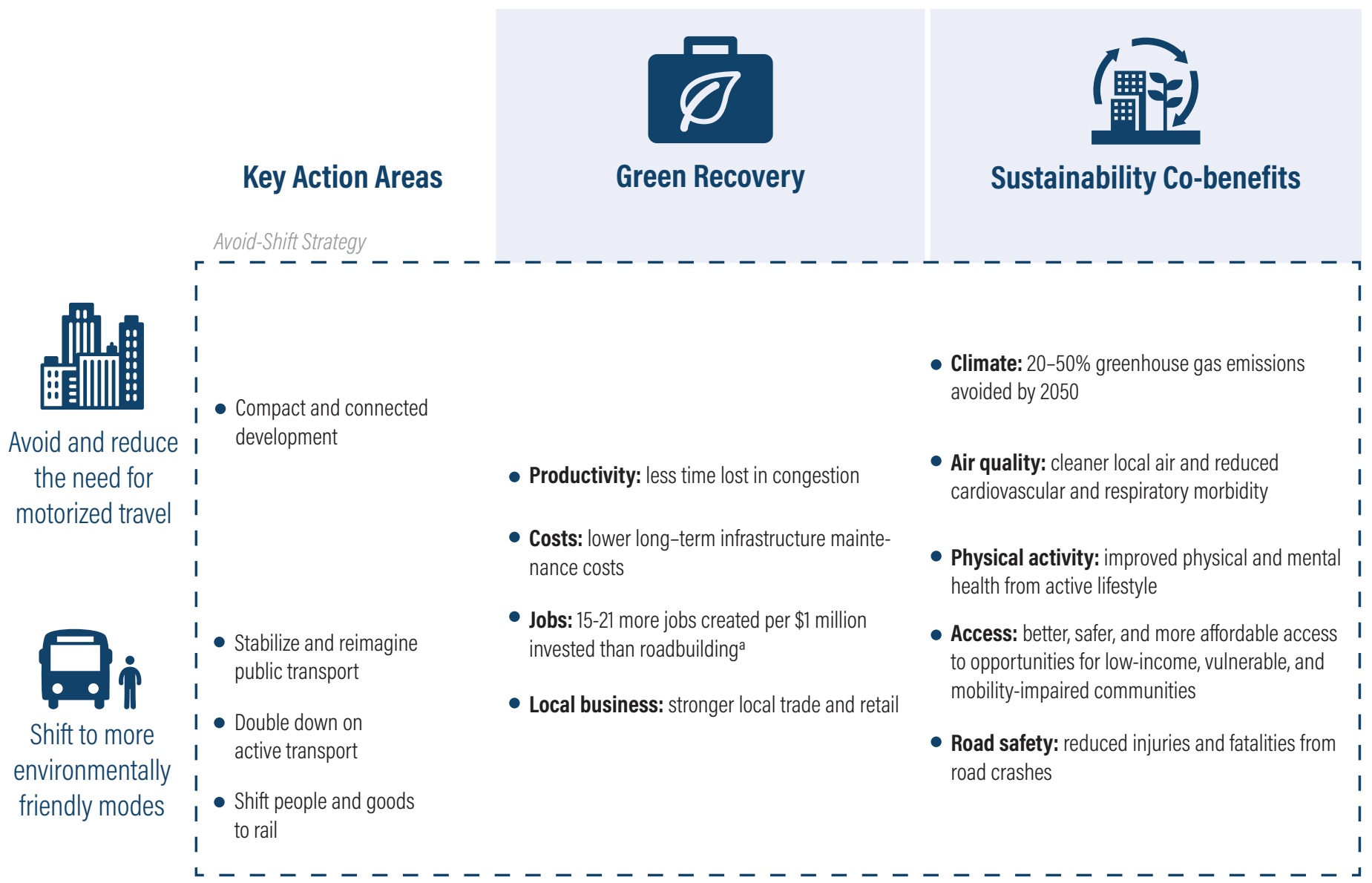

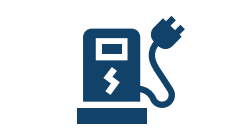

Improve energy

efficiency of

transport modes
- Jobs: 7-13 more jobs created per $\$ 1$ million invested

- Accelerate electrification and efficiency

- Fund clean research and development and just transition in installing charging stations than building roads ${ }^{\mathrm{a}}$

- Green economy: 52 million new jobs created through green economy by $2030^{\mathrm{b}}$

- Low abatement costs: zero emissions for harder-to-abate sectors costs less than $0.5 \%$ of global GDP with long-term return on investment ${ }^{c}$
- Zero emissions: introduce next generation of zero-emission fuels and energy storage

- Livelihoods: train and transition workforce from carbon-intensive sectors to high-quality green careers

- Resiliency: cheaper total cost of ownership for zero-emission vehicles frees up funds elsewhere

Note: GDP = gross domestic product.

Sources: a Gulati et al. (2020); Engel et al. (2020); b C40 (2020b); ' ETC (2018). 
million) invested, almost twice the low-end estimate for jobs created installing EV charging infrastructure (Engel et al. 2020). In a 2011 evaluation of 58 transport projects across various U.S. cities, a study found that each $\$ 1$ million spent on bicycle and pedestrian projects created 11.4 and 10 jobs, respectively-including direct, indirect, and induced jobs-compared to 7.8 jobs per $\$ 1$ million spent on road-only projects (Garrett-Peltier 2011). Another 2011 study that analyzed reported job creation data after the 2008 Great Financial Recession found that public transportation yielded 70 percent more job hours per stimulus dollar spent than the same dollar spent on building new highways (Smart Growth America 2011). In Colombia, expanding urban bus rapid transit (BRT) networks creates 37 percent more annual direct employment than building new road infrastructure per $\$ 1$ billion invested (Schwartz et al. 2009). The high employment multiplier for public transport is due, in part, to transit infrastructure's requiring fewer materials and less space than roadbuilding, meaning a higher share of investment goes directly to labor, and to the diverse skill sets needed to administer, maintain, and operate a public transport system (Barry 2010; Mallett 2020).

In developing regions, the employment impact of green transport investments may be higher. In 21 developing countries, \$2.7 trillion in green transport investment opportunities, namely, mass transit and vehicle electrification, could create 53.4 million new direct jobs by 2030 (IFC 2021) (see Figure 5). Green urban transport investments create the most direct new jobs compared to investments across 10 proposed low- and zero-carbon sectors. Transport infrastructure construction and operation jobs often provide competitive wages for workers with low levels of education attainment (Kane and Puentes 2015). However, in low-income countries, informal workers, predominately young men, hold up to 80 percent of urban public transport jobs and are often subject to exploitative labor conditions (ILO 2018, 2020).

Figure 5 | Direct jobs created per \$̦1 million spent in emerging regions

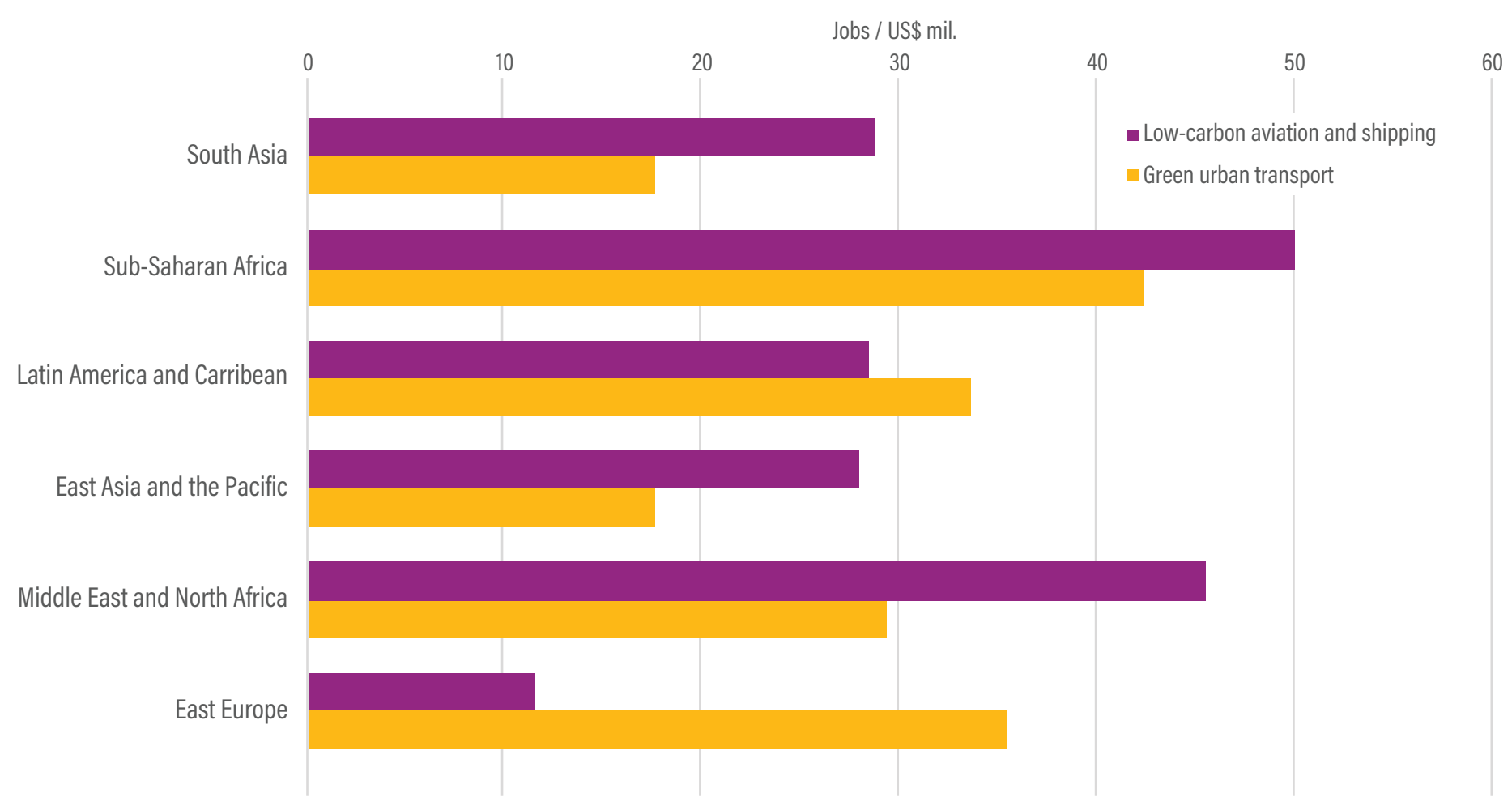


The long-term economic benefits of sustainable transport go beyond job creation. Safe active transport infrastructure accommodates more inclusive modes of travel and increases tourism, consumer spending, and real estate values. Case studies in New York City suggest businesses along corridors that implemented new bicycle lanes saw local trade increase by almost 50 percent (Rajé and Saffrey 2016). Public transport reduces consumer travel costs time and traffic congestion, and increases business productivity. In a more recent study, the American Public Transportation Association (APTA) projects $\$ 5$ billion in annual economic impact per $\$ 1$ billion invested in public transport through 2040 (APTA 2020).

\section{Climate Action}

Most studies conclude that despite lower levels of global emissions due to reduced economic activity, public and private stakeholders must institute additional climatecentered policies and fiscal measures to meet long-term Paris Agreement targets (IEA 2020a; Lahcen et al. 2020; Shan et al. 2021). According to the SLOCAT Partnership, transport $\mathrm{CO}_{2}$ emissions would need to decline to 2-3 gigatons (Gt) by 2050 to meet Paris Agreement targets, roughly 70-80 percent lower than 2015 emission levels and $16 \mathrm{Gt}$ lower than projected 2050 business-as-usual estimates (SLOCAT 2018). One analysis by C40 suggests a green recovery could slash greenhouse gas emissions by more than half by 2030, as opposed to a business-as-usual scenario; 22 percent of emission savings would derive from the transport sector ( $\mathrm{C} 4 \mathrm{O} 2 \mathrm{O} 2 \mathrm{Ob})$.

Electrifying internal combustion engine vehicles is an important start. A recent study by the International Council on Clean Transportation (ICCT) suggests that accelerated EV adoption and improved fuel efficiencies could account for up to 85 percent of the transport-related GHG emission reduction needed to realize the Paris Agreement's 2050 target (ICCT 2020). However, this can vary by country and electrification is not a climate panacea and does not ensure safe, equitable transport.

Investing in public and active transport infrastructure is essential to managing transport demand, avoiding unnecessary motor vehicle travel, and promoting more environmentally friendly and accessible modes, such as walking, pedal and electric bicycles, rail, and buses (Fransen et al. 2019). These strategies could potentially reduce GHG intensity in the transport sector by $20-50$ percent by 2050, below a 2010 baseline (SLOCAT 2018). Both mass transit and active transport are substantially less carbon- intensive per passenger-kilometer than private vehicle travel, including battery electric vehicles when accounting for life-cycle emissions (ITF 2020b) (see Figure 6).

\section{Health and Equity Benefits}

Mass transit and active transport also create healthier, safer, and more inclusive cities. Transport's main purpose is to connect people to essential goods, services, and opportunities like jobs, food, education, and health care. Increasing sprawl and lack of affordable and accessible mobility options have left essential services too far away or too costly for the most underserved or marginalized communities to reach (Venter et al. 2019; Mahendra and Seto 2019). Sprawling and disconnected cities are also more emission-intensive, have higher long-term infrastructure maintenance costs than compact cities, and, in some cases, are less economically productive per capita (Zhao et al. 2016; Gouldson et al. 2019; CUT 2019).

Cities that prioritize highway building over public transport and compact development disproportionately benefit wealthier residents while leaving poorer residents disproportionately impacted by the negative externalities, including poor air quality, unaffordable transport options, dangerous walking infrastructure, and exclusion from opportunities (Lucas et al. 2016). Safe and affordable public transport is also critical to women in low-income countries, who often have fewer resources, face greater physical risks in public spaces, and take shorter, more care-related trips than men. However, in most cases, transport planning processes fail to account for women's travel needs, hindering entrepreneurship, access to food and health care (including maternal health), and their economic contribution at a household, local, and national level (Jennings 2020).

High rates of driving and unsafe infrastructure could further increase road crashes. Traffic crashes kill 1.35 million people every year and are a leading cause of death, especially among children (WHO 2018). Deaths disproportionally occur in low- and middle-income countries, which account for over 90 percent of the world's road deaths despite having only 60 percent of the world's registered vehicles. The World Bank estimates that halving traffic deaths could add 7-22 percent to GDP per capita over 24 years to select lower-middle-income countries (World Bank 2017).

Additionally, both increasing vehicle use and sprawl have led to lower rates of active travel and physical activity, with consequent declines in health (Brownson et al. 2005; 
Figure 6 | GHG emissions per passenger kilometer (pkm) by transport mode

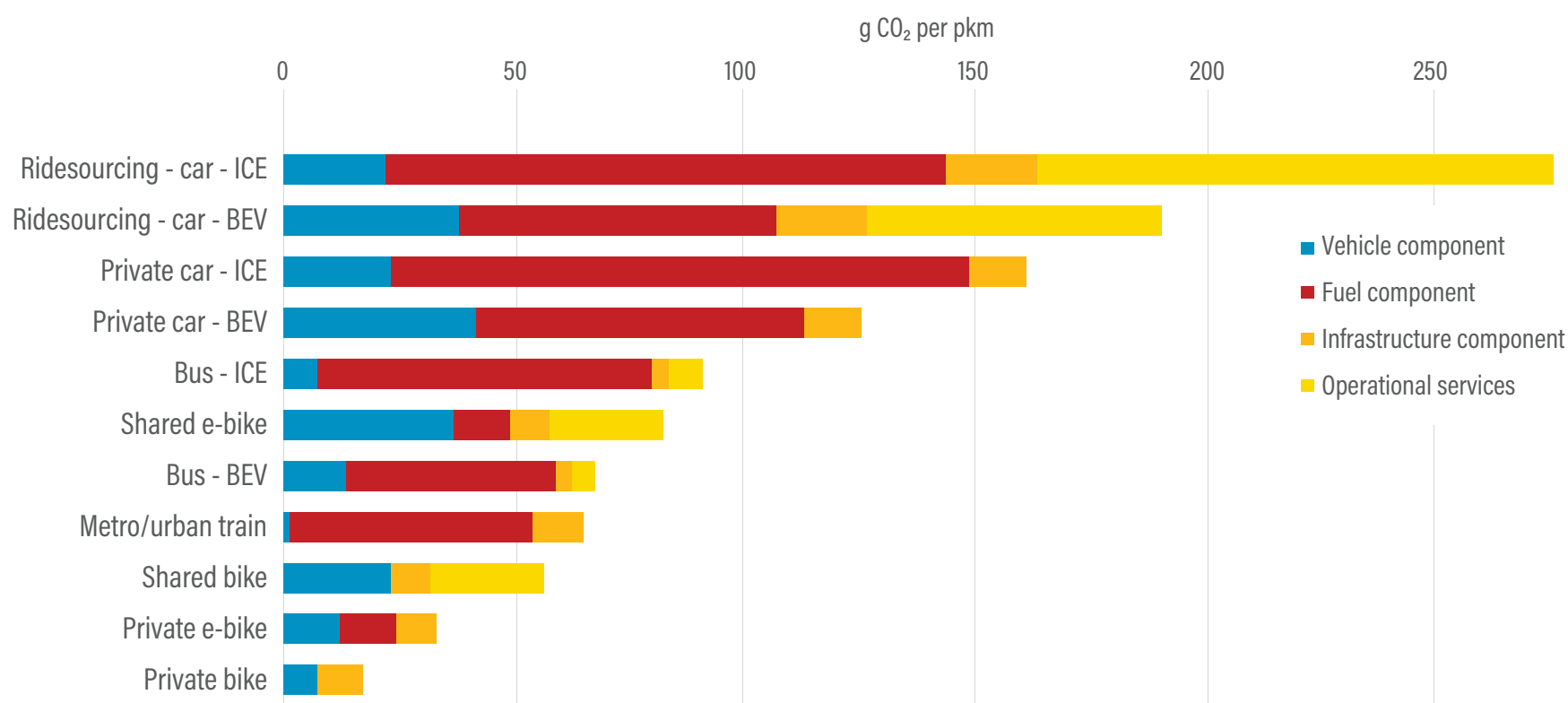

Note: $\mathrm{GHG}=$ greenhouse gas; $\mathrm{g} \mathrm{CO}_{2}=$ grams of carbon dioxide; e-bike = electric bike; ICE = internal combustion engine; $\mathrm{BEV}$ = battery electric vehicle.

Source: ITF (2020b).

Mackett and Brown 2011; Ewing et al. 2014). Globally, lack of physical activity accounts for 5.3 million premature deaths per year (Lee et al. 2012). Health experts estimate that just 30 minutes of physical activity five days a week dramatically reduces risks of heart disease, stroke, breast and colon cancer, depression, and type II diabetes (C40 2020b).

Automotive pollutants are also a leading cause of cardiovascular and respiratory diseases in urban areas. Globally, ambient air pollution kills 3.5 million to 4.2 million people every year by some estimates (Anenberg et al. 2019; WHO 2019). Transport sources account for 30 percent of particulate air pollution in Organisation for Economic Co-operation and Development cities worldwide, and as much as 60 percent in cities of the developing world ( $\mathrm{C} 4 \mathrm{O}$ 2014). Moreover, the urban poor are disproportionately exposed to traffic pollution and experience higher rates of pollutant-related morbidity (Pratt et al. 2015; Hajat et al. 2015). According to $\mathrm{C} 4 \mathrm{O}$, a transition to clean transport would avert 86,000 deaths (C40 2019).

\section{TRANSPORT-RELATED STIMULUS SPENDING AND POLICY RESPONSES}

Early government stimulus prioritized health care, frontline worker well-being, enterprise support, and unemployment. While the environmental impacts of these funds are not easily apparent, Vivid Economics estimates that G2O countries spent at least 30 percent of the total $\$ 15$ trillion in announced global stimulus in sectors that will have lasting environmental impacts, such as the hard-hit transport sector (Vivid Economics 2021). Vivid Economics expects a greater share of stimulus funds to go to energy- and nature-related sectors as governments transition priorities from short-term crisis response to long-term economic recovery. However, as of February 2021, overall stimulus spending in 15 of the G20 countries has net-negative environmental contributions. At its most negative extreme in 2020, Rhodium Group found that only 1.1 percent and 0.3 percent of the respective funds of the largest stimulus spenders, the United States and China, had climaterelated priorities (Larsen et al. 2020). And in fact, both countries have committed substantial fiscal support to hard-hit automotive manufacturers, while simultaneously 
weakening vehicle emission standards (Rott and Ludden 2020; Bloomberg News 2020). One of the largest categories of global transport investments, $\$ 125$ billion, went to bail out the aviation sector. Of these funds, only 20 percent ( $\$ 24$ billion) were conditional on implementing modest environmental improvements (Energy Policy Tracker 2020).

Despite a preponderance of fossil fuel-related investments, there are many examples of green transport investments that aim to reduce emissions, stabilize access to essential services, improve public health, create jobs, and boost the economy. This report evaluates a sample of 266 national transport-related policies, representing a total of
$\$ 298$ billion quantified stimulus commitments. We derive five major categories that best capture how countries are prioritizing green transport spending (see breakdown of announced transport-related stimulus spending in Figures $7 \mathrm{a}-\mathrm{c}$ ). We discuss the methodology for selecting this taxonomy in greater detail in Appendix A.

Below we review the key transport areas where governments have taken green action. In addition to the spending captured by the Energy Policy Tracker mentioned above, we describe policy-based actions taken on the subnational level, particularly in cities, as stimulus packages alone do not illustrate the breadth of COVID-19 responses by governments.

Figure 7A | Total transport-related stimulus spending (US\$̦ billions)

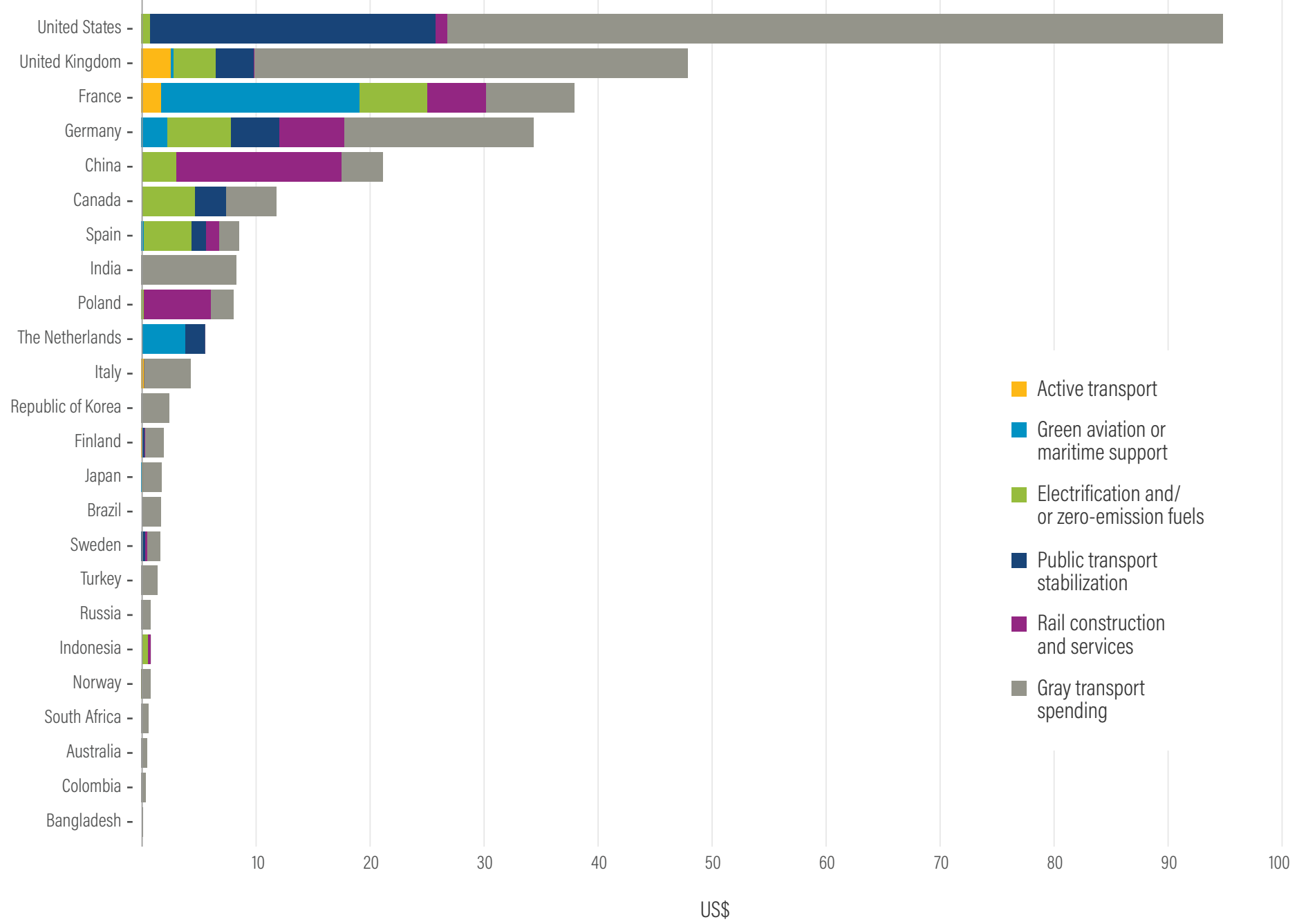


Figure 7 B | Transport-related stimulus spending (\% of gross domestic product)

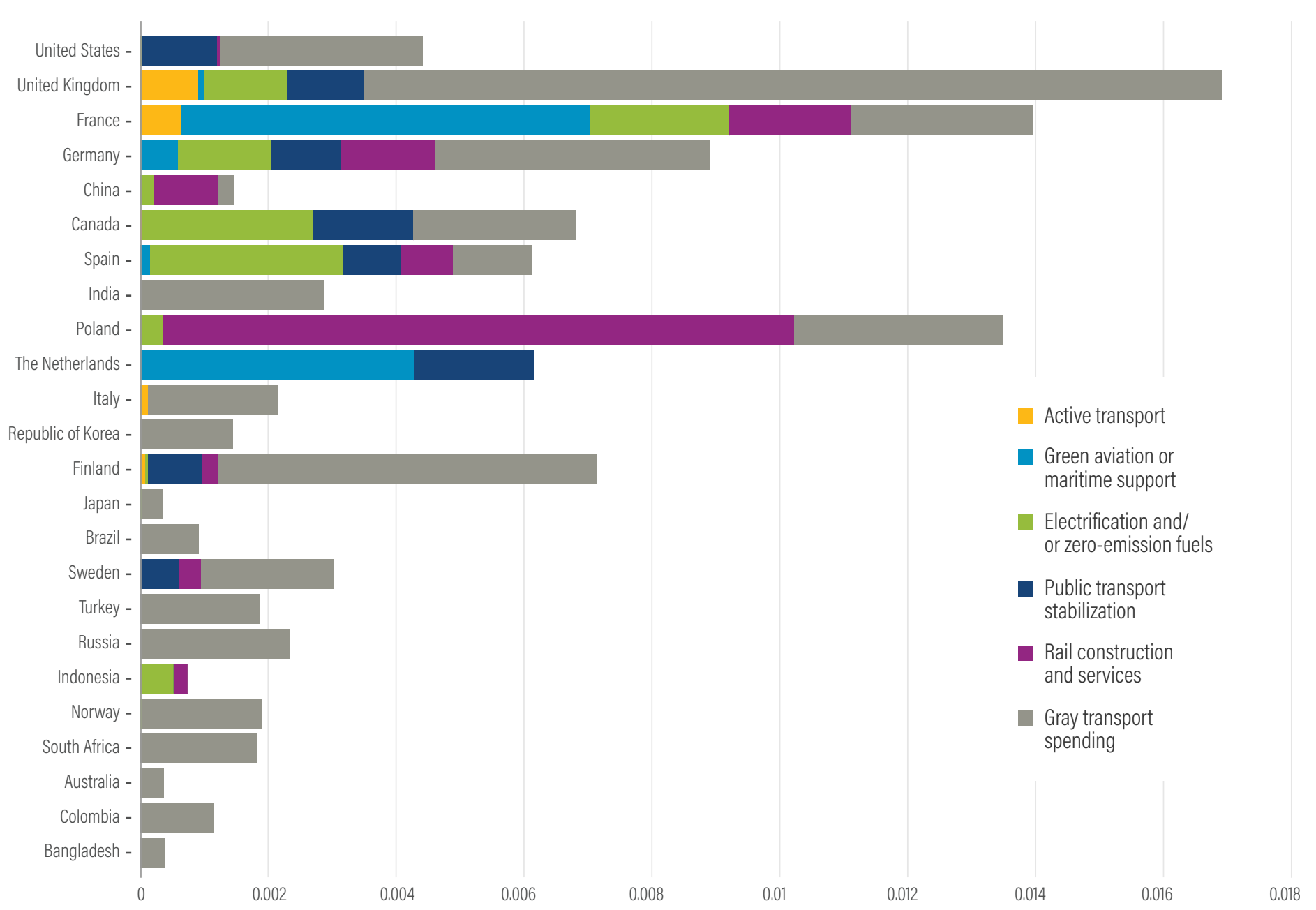




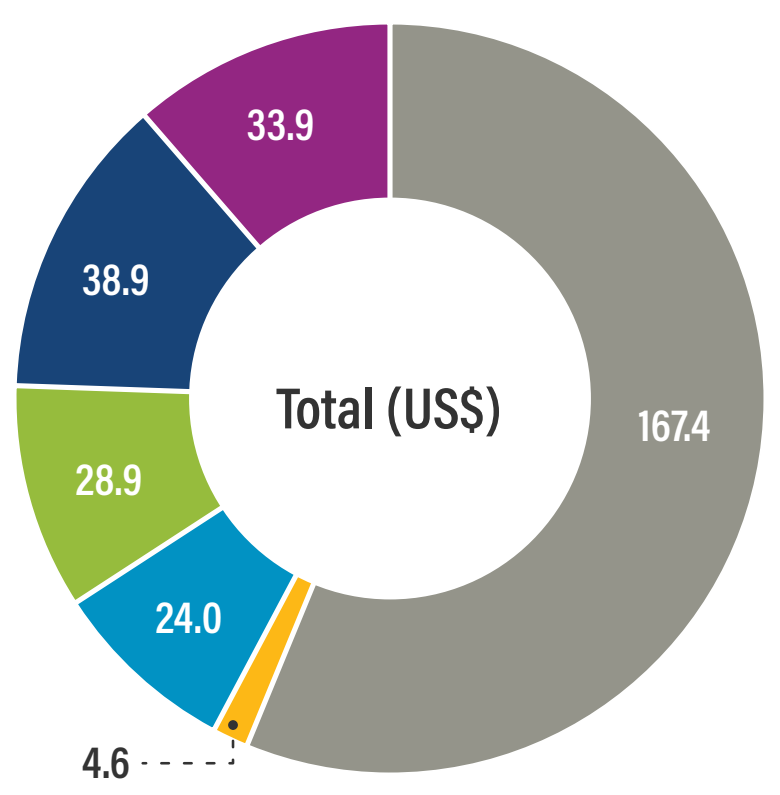

Active transport
Green aviation or maritime support
Electrification and/ or zero-emission fuels

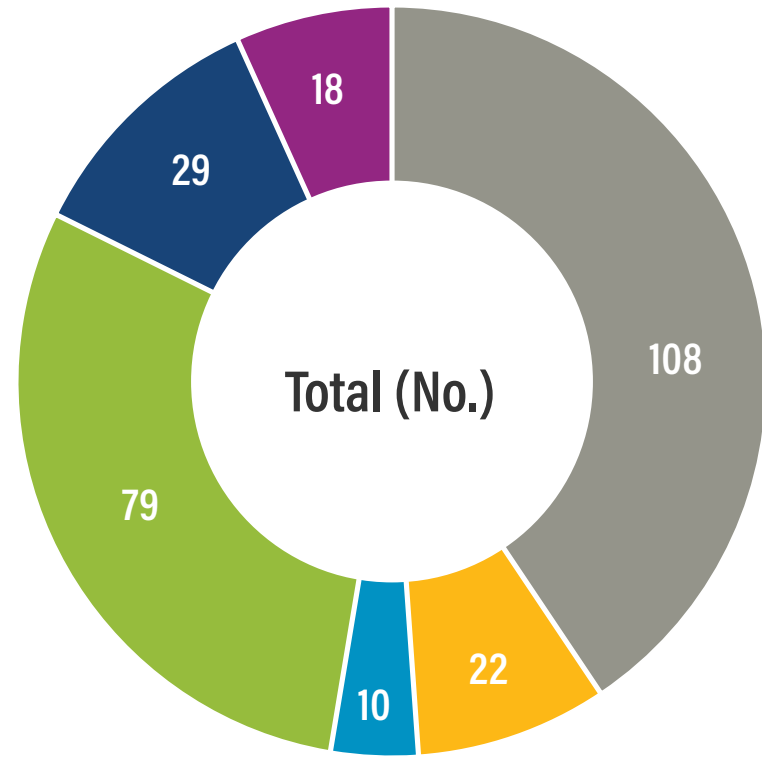

Public transport stabilization
Rail construction and services
Gray transport spending

Notes: Energy Policy Tracker captures only 3 to 5 percent of total stimulus commitments. Policies not related to energy, such as unemployment support, are not included. Additionally, of the 266 mobility policies tracked, 47 did not quantify monetary commitments. Policies include both unconditionally and conditionally green investments, such as investments in dirty sectors that have environmental conditions with or without enforcement mechanisms. Due to the size of some investments and the scale of total global investment, some categories of country spending could not be shown in the graph, though may be found in the Appendix. Analysis last updated February 2, 2021.

"Gray transport spending" denotes spending that falls under one of five categories. These categories include aviation sector bailouts without climate conditions; internal combustion engine (ICE) vehicle manufacturing bailouts; ICE vehicle subsidies, tax repeals, or emission standard rollbacks; and biofuels. For further definition and explanation for these categories, see Appendix A.

Source: WRI analysis via Energy Policy Tracker, February 2021.

\section{Public Transport Stabilization}

\section{Many countries established public transport emergency relief funds at the outset of the pan-}

demic. The U.S. Coronavirus Aid, Relief, and Economic Security (CARES) Act, which committed $\$ 25$ billion, stands out as the largest. While the CARES Act provides a lifeline to frontline transport workers and ailing public transit agencies, it is still not enough to fill revenue gaps (Wilson 2020; Fortunati 2020). In December 2020, the United States committed an additional $\$ 14$ billion in emergency funding to public transport agencies (not tracked by Energy Policy Tracker). ${ }^{1}$

On a municipality level, public transport agencies have instituted myriad measures to ensure either safety or special services during the pandemic, from rear-door boarding to digital payments, improved air filtration and circulation, reduced fares for essential workers, and reduced transit capacities (NUMO 2020). Some cities are implementing additional public transport priority infrastructure. Porto Alegre, Brazil, is doubling the length of exclusive bus lanes, having just implemented 13.4 kilometers $(\mathrm{km})$ of dedicated lanes, with an additional $6.5 \mathrm{~km}$ coming this year (Roth 2020). Vancouver; Washington, DC; Paris; London; and San Francisco have announced similar plans to expand bus-only lanes (Welle 2020). While these may not constitute stimulus measures, they are important in keeping public transport functioning for essential and low-income workers. 
East Asia public transport agencies are responding innovatively. South Korea and China have maintained health standards by mandating mask wearing, increasing frequencies during peak hours to reduce crowding, and encouraging cashless fare payments, among other measures (Lee 2020; Liu et al. 2020a). Seoul's metropolitan authority created a mobile app so passengers could monitor transit congestion and timetable changes. Seoul also installed 10 enclosed "smart shelters" that monitor temperatures of transit users and deny entrance to those with a fever (Seo and Berlinger 2020).

\section{In low-income countries especially, the need to sustain public transport services is critical. Nige-} ria, the most populous country in Africa, has committed almost \$200 million to compensate informal and smallscale public transport operators for lost revenues and has invested in higher-capacity, more fuel-efficient buses (HVT 2020). While Nigeria has made efforts to cushion those who rely on and are employed by public transport, one Nigerian research group points out that speed limit reductions, safe pedestrian and bicycle facilities, and mass transit integration are also necessary to ensure sustainable outcomes (John 2020). Moreover, interviews in Nigeria suggest that drivers, especially women drivers who had to balance household and health-related tasks, were unable to apply due to the lengthy application process and requirement for formal operating licenses, which were often incomplete (Jennings 2020).

\section{Active Transport}

The emergence of additional national funding for active transport shows promise in how national fiscal programs could shape active transport strategies in the future. According to Energy Policy Tracker and other sources, Europe has led the way in designating national finance to active transport infrastructure. Some countries committed more funds than others, with Finland committing the most, at $\$ 10.65$ per person, and Spain the least, at \$0.23 per person (McCarthy 2020). The United Kingdom, which announced a £2 billion ( $\$ 2.7$ billion) national active transport plan, includes measures for bicycle- and bus-only streets, bicycle repair vouchers and cycle-to-work schemes that offer discounts for new bicycle purchases, and fasttracking electric scooter- and bike-share pilots (UK Department for Transport 2020). The United Kingdom, which aims to increase bicycling mode share by 50 percent by 2025, will also a establish a national commissioner on bicycling and walking, with the intention of improving long-term governance and budgeting for active transport.
City governments have responded to this new demand for pedestrian and cycling spaces by restricting car access on certain streets, creating pop-up bicycle lanes, lowering vehicle speed limits, opening street spaces for outdoor dining, widening sidewalks, and accelerating active transport plans, among other actions (Schwedhelm et al. 2020). An exploratory analysis of COVID-19 mobility responses collected by the Pedestrian and Bicycle Information Center identifies 390 interventions that reallocated or built public spaces that impact bicyclists and pedestrians (PedBikeInfo 2020; Combs and Pardo 2021). While 195 interventions are stated to be only temporary, 100 are anticipated to last indefinitely.

In Europe, 37 of the 94 largest cities have announced or are currently implementing bicycle plans in response to COVID-19 (ECF 2020). The majority, roughly 75 percent, are dedicated to building new bicycle lanes and paths, with the remainder of funds going to widening sidewalks and implementing traffic calming measures and car-free zones. London has also increased its congestion charge from $£ 11.50$ to $£ 15$ and implemented an ultra-low emission zone and low emission zone near the city's center to help encourage a mode shift to active transport (Warren 2020). Latin American cities are also expanding bicycle infrastructure. Most notably, Bogotá, Colombia, created $84 \mathrm{~km}$ of emergency bicycle lanes on the eve of COVID-19 shutdowns to help essential workers, and it has announced a four-year plan to add $280 \mathrm{~km}$ of bike lanes to the existing 550-km network (Jaramillo 2020).

\section{Electrification and Zero-Emission Fuels}

\section{With vehicle sales dropping, some countries are vying to be the next global leader in $\mathrm{EV}$ produc-} tion and adoption. In March, Germany committed \$6.7 billion in recovery spending to advance EVs. The German government will double existing purchase subsidies for EVs under $€ 40,000$ ( $\$ 48,532)$, raise the motor vehicle tax for polluting cars, install charging infrastructure, and subsidize electric bus procurement until the end of 2021 (Hall and Lutsey 2019; Walton and Jonker 2020). Meanwhile, in May, France announced a $\$ 9$ billion bailout for the country's auto industry, which included environmental conditions such as strict compliance with European $\mathrm{CO}_{2}$ emission performance standards and commitments on increasing the share of low- and zero-emission engines (Vanier and Isaac 2020).

South Korea's green stimulus also emphasized EV sales and production. As part of the country's "Green New Deal," the government set EV and hydrogen fuel cell 
vehicle sale targets of 1 million and 200,000 by 2025 , respectively, up from 91,000 and 5,000 in 2019 (Shin and Cha 2020; Yeon-joo and Hyo-jin 2020). Initiatives include extending and increasing purchase subsidies for passenger cars until 2024 (originally set to expire in 2022) and for trucks and buses until 2025, as well as scrapping 1.2 million diesel vehicles. South Korea is also using production mandates and tradeable credits that incentivize manufacturers to achieve a 15 percent share of 2020's sales from electric, hydrogen, or hybrid vehicles.

Though unquantified in Energy Policy Tracker, India instituted several electrification initiatives as part of statelevel recovery programs and under the multiphased Faster Adoption and Manufacturing of Hybrid and EV (FAME) scheme. New Delhi commissioned 671 electric buses and 241 charging stations, and set a target to achieve 25 percent EV registration by 2024 through purchase incentives supported by a Rs10,000 crore ( $\$ 1.3$ billion) fund ( $E T$ Energy World 2020; The Hindu 2020). India's phased FAME scheme, which took effect in 2015, sets targets for electrifying buses, commercial vehicles, and three-wheeled auto-rickshaws-the latter accounting for 20 percent of trips in some cities (Mani et al. 2012; Argus Media 2020a). The Energy and Resources Institute estimates that further advancing emission standard mandates and electrification incentives-such as offering 50 percent rebates for EV purchases, installing more charging infrastructure, and procuring more zero-emission buses-could have an annual net-stimulus benefit of Rs138,00o to Rs240,00o crore (roughly $\$ 185$ million to $\$ 322$ million) (Shankar and Avni 2020).

\section{Rail Construction and Services}

\section{Rail stands out as one of the largest transport} funding categories across countries. During the 2008 Great Financial Recession, 26 percent of global green stimulus funds ( $\$ 135$ billion) went to rail, making it the largest category of green stimulus investments across sectors (Robins et al. 2009). As of June 2020, countries have collectively commissioned or planned over 16,000 $\mathrm{km}$ of urban metro and light rail-65 percent of which are in low- and middle-income countries-and 32,000 km of intercity high-speed rail (IEA 2020a). While some of these projects were commissioned before the pandemic, and budgetary disruption may stall the completion of some projects, several countries are increasing rail investment.

Since 2009, China has invested almost $¥ 800$ billion ( $\$ 115$ billion) per year in expanding its national rail network (Xin 2020). In the first half of 2020, as part of its national infrastructure stimulus, China committed an additional $\$ 14$ billion to rail, including high-speed rail. China's comparatively modest increase in rail investments is part of the government's stated goal to increase economic prosperity and reduce emissions (Tang 2020; Argus Media 2020b).

France and Germany have also committed over $\$ 5$ billion each to maintain a high level of investment and develop new national railway services as part of their green stimulus packages. Germany's Deutsche Bahn rail corporation has also announced plans to pilot zero-emission hydrogen-powered trains by 2024 as part of the country's new hydrogen strategy (Frangoul 2020). Meanwhile, in November, India awarded $\$ 3.3$ billion for its first-ever high-speed rail project to connect Mumbai and Ahmedabad (Dasgupta 2020).

\section{Green Aviation Support}

\section{Some aviation sector bailouts contained first-of- a-kind environmental conditions. In its $€_{7}$ billion} bailout of Air France, the French government introduced two first-of-their-kind climate conditions: a 50 percent reduction of aviation emissions by 2030 (in comparison to 2005 emission levels) and a minimum standard of 2 percent renewable fuel by the same year (Bannon 2020). The conditions set a target of reducing domestic emissions, in part, by shifting long-distance travel to rail from air travel under 2.5 hours. KLM (the second half of the KLM-Air France group) received a similar climate-conditional support from the Dutch government (Dunn 2020).

Aviation constitutes 2.5 percent of total GHG emissions, and as a result high-altitude interactions between GHG pollutants and the atmosphere disproportionately account for 3.5 percent of human-forced climate warming (Lee et al. 2021). Without intervention, aviation could consume 12-27 percent of the global carbon budget for the $1.5^{\circ} \mathrm{C}$ temperature-rise goal by 2050 (Pidcock and Yeo 2016). Sustainable aviation fuels (namely, renewable biofuel) offer one possible solution. According to the International Civil Aviation Organization, converting 100 percent of current aviation fuel to biorenewables could reduce the emissions of international flights by 63 percent by 2050 (ICAO 2017). Consequently, the Dutch government mandated that KLM introduce 14 percent biorenewable aviation fuels to its fleet by 2030 (Government of the Netherlands 2020). France invested $€ 1.5$ billion over three years to support research into carbon-neutral aviation technology to launch a clean fuel airplane by 2035 (Hepher 2020). 
With more funds to be announced in the coming months and years, countries, cities, and companies are now tasked with shaping the sustainability of our mobility systems for years to come. For instance, in March 2021, U.S. President Joe Biden proposed the $\$ 2$ trillion "American Jobs Plan," which includes $\$ 174$ billion for vehicle electrification and $\$ 165$ billion for public transport and rail in March (Jaeger et al. 2021). Meanwhile, environmental ministers across the African continent have declared ambitions for a green stimulus program (UNEP 2020), with countries like Nigeria ending fossil fuel subsidies and offering shortterm incentives for renewable off-grid energy generation (Akrofi and Antwi 2020).

Therefore, we see intersectional opportunities for crosssector stakeholders to consider when allocating funds and identifying interventions. This is not an exhaustive list of actions, and indeed the approaches and implications vary across incomes and geographies. Moreover, this paper does not discuss behavioral or "avoid" strategies (reducing travel demand through high-density land use planning or promoting work-from-home initiatives, etc.), which require a more comprehensive analysis beyond the scope of this paper. Nonetheless, the priorities below provide a useful roadmap to sculpting a recovery through sustainable transport.

\section{Opportunity \#1: Stabilize and Reimagine Public Transport}

\section{Finding:}

Public transport is going through immense upheaval and requires stabilization. Not only ensuring the survival of but strengthening public transport creates and sustains more jobs than car-oriented infrastructure investments, such as highway building. Preliminary research suggests that doubling public transport investment, reducing or eliminating fares, and electrifying buses all have enormous potential to create and sustain jobs (Harsdorf et al. 2020). Stabilizing and investing in the long-term recovery and prosperity of public transport also improves equal access to jobs and services, improves road safety, supports smart urban growth, and limits carbon emissions.

\section{Action areas:}

Stabilize public transport liquidity and services. Facing dwindling revenues from fares, public transport agencies are now tasked with dedicating further resources to ensure physical distancing and follow sanitation mandates. Public transport risks permanent reductions in ridership, which stands to hurt low-income communities the most while losing good local jobs. Further investments must also be made to ensure that public transport is safe to use, resilient, and affordable, and provides quality and timely service while protecting the health of its riders.

\section{Build bus-priority and other public transport} infrastructure. Dedicated bus lanes and other forms of transit priority can help cities move people to their destinations faster and can increase ridership in the future (Welle 2020). National governments can include bus infrastructure in recovery programs. Cities can create quick-build bus priority lanes, such as by painting dedicated bus lanes on high-volume routes or creating road space for buses to jump traffic queues (Bliss 2019). Dedicated bus lanes dramatically decreased travel times in cities such as Curitiba, Brazil, which pioneered the bus rapid transit (BRT) model almost 50 years ago (Jacques and Levinson 1997). In Seoul, BRT lanes implemented in 2004 increased bus operating speeds on one major route by 85 percent and increased general traffic speed by almost 8 percent. In some countries, other mass transport projects, such as metro or light rail, can be given proper financing and implemented sooner.

Reimagine public and private finance. Both public and private actors must enact new approaches to finance transit operations and capital investments. Policy solutions include reallocating capital investments from highway budgets to public transport and adopting congestion pricing, carbon pricing, and parking fees to simultaneously raise funds for public transport, curb private vehicle demand, and support reallocation of public space (Gulati et al. 2020; Welle and Avelleda 2020). In 2019, for instance, London's congestion charge generated almost $\$ 303$ million in gross revenue, which is being reinvested in the city's public transport system (Transport for London 2019). In some contexts, public authorities can also leverage private finance for transit infrastructure and development projects by introducing contractual instruments that derisk investments and encourage publicprivate participation, as evidenced by a WRI case study in Brazil (Leipziger and Lefevre 2015). 


\section{Finding:}

Walking and bicycling promote healthy lifestyles, are emission-free, spur regional economic benefits, such as higher consumer spending, and are integral to people's access to public transport (Flusche 2012; Gulati et al. 2020). Smart investments can also reduce the rate and severity of road crashes, from protected bicycle lanes on busy city streets to wider sidewalks and low-speed zones, or shared spaces (Welle et al. 2018). Moreover, pedestrian and bicycle facilities require less capital than road projects and can create more jobs per dollar, as U.S. and EU studies reveal (Garrett-Peltier 2011; Engel et al. 2020).

\section{Action areas:}

\section{Allocate national funds and governance to active transport and road safety. National funding for active mobility is lacking across countries. A 2016 United Nations (UN) Environment Programme report on policies in 25 low-to-middle-income countries across Africa, Asia, and Latin America found that most had a policy at some level intended to give cycling and walking more attention, though often these were relatively insubstantial mentions in general mobility strategies (UNEP 2016).}

In some cases, national finance can come in the form of bicycle subsidies, tax exemptions, and business partnerships, such as the United Kingdom's Cyclescheme, started in 1999 (Cyclescheme 2021). Several countries have enacted or introduced policies that offer rebates and tax credits for purchasing bicycles, equipment, and/ or electric bikes, including France, Italy, Portugal, and the United States (Zipper 2021). Companies can complement these government efforts by establishing commute programs that encourage employees to use active mobility (and public transport) in so-called travel demand management programs.

\section{Build more bicycle and pedestrian infrastructure.} Bicycle use and sales are at a record high, with many cities responding by building new bicycling infrastructure. This highlights the need for quality spaces to socially distance, which reveals that much pedestrian infrastructure is woefully inadequate, characterized by narrow sidewalks, uneven pavement, and unsafe conditions for pedestrians, who in some regions make up the bulk of traffic. National and local-level investments in safe infrastructure can help cities develop safe, connected, cohesive bicycling infrastructure that reduces emissions. For example, the Netherlands' experience shows that a mix of funding and policies on road safety can result in very high rates of cycling use. One scenario-based analysis found that incrementally increasing the mode-share of bicycling to $15-40$ percent by 2050 (depending on the region) could save $\$ 24$ trillion in energy and vehicle cumulative infrastructure costs between 2015 and 2050, and cut $\mathrm{CO}_{2}$ emissions from urban passenger transport by nearly 11 percent in 2050 compared with business-as-usual bicycling trends (Mason et al. 2015).

\section{Opportunity \#3: Accelerate Electrification and Efficiency}

\section{Finding:}

Vehicle electrification holds the greatest potential to decarbonize transport, particularly in leading markets. Research also shows that electrification creates jobs, especially in the installation of charging infrastructure, and reduces air pollutant-related morbidity. While EV sales spiked in 2020, despite economic contraction, achieving net-zero vehicle emissions by 2050 will require accelerated EV adoption rates (see Figure 8) (Lebling et al. 2020). Economic recovery and other government programs can accelerate vehicle electrification (Zhang et al. 2014), including of bus and freight fleets. For instance, the International Council on Clean Transportation found that governments that instituted the highest fiscal incentives immediately following the 2008 Great Financial Recession (e.g., those of Norway, the Netherlands, and California) achieved the largest increases in EV market share by 2013 (Mock and Yang 2014).

In countries with low energy access and carbon-intensive energy grids, emission savings stemming from plug-in EV adoption would be offset by increased demand on a dirty and/or inefficient power supply (Kennedy et al. 2019). Therefore, investments in EV adoption and production must be accompanied by a transition to renewable energy generation and smarter vehicle-grid integration.

\section{Action areas:}

\section{Institute a robust blend of policies and incentives} to accelerate EV adoption. Solutions vary greatly based on a geography's market readiness and charging availability. Policies should mix market "pulls," inducing 


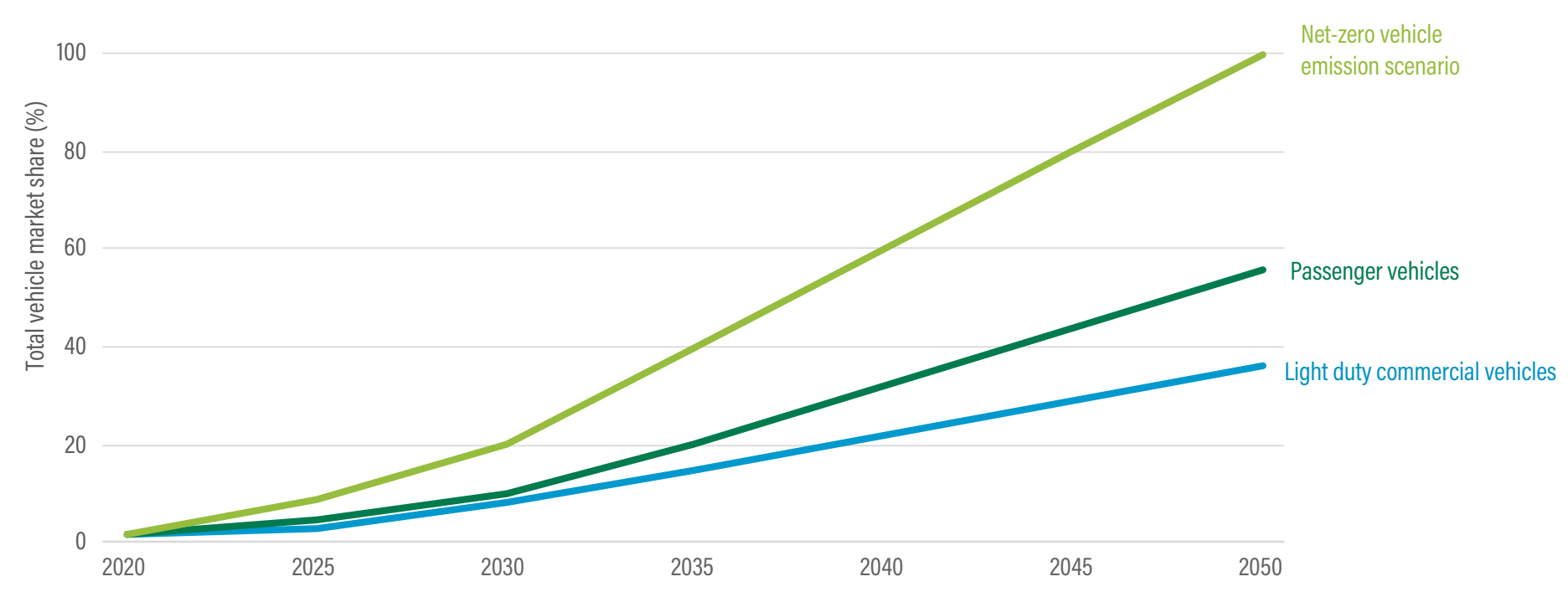

Source: BNEF (2020).

EV supply and demand through fiscal and nonfiscal incentives, and "pushes," through directives for EV procurement and limits or prohibitions on ICE vehicle production (Axsen et al. 2020) (see Table 1). These regulations should align public and private stakeholders, as well as country and city levels. In the Netherlands, the Dutch Environment Ministry and 14 municipalities signed a joint agreement to enact zero-emission zones for delivery trucks by 2025, with the expectation of incorporating 30 municipalities in the agreement by the end of 2021 (Manthey 2021). As part of this collaborative initiative to decarbonize urban deliveries, entrepreneurs and companies can apply for subsidies when purchasing or leasing electric delivery vans and trucks, and can reduce their costs of installing public charging points (Wallbox 2020).

\section{Leverage public resources and private finance to build public charging infrastructure and create} jobs. Globally, 290 million charging points are needed by 2040 to accommodate projected EV demand, including 12 million public charging stations, which equates to roughly $\$ 500$ billion in investment (BNEF 2020). The installation and manufacturing of charging infrastructure supports more than 12 jobs per million dollars invested (IEA 2020a). These jobs typically do not require an advanced degree (45 percent of workers in the clean energy sector do not hold a university degree), facilitating an easier workforce transition (Marcacci 2019).
Private sector investment has predominately driven the installation of charging infrastructure. Private companies in the United States (e.g., vehicle manufacturers and charging station providers) and utility companies have invested $\$ 2.8$ billion and $\$ 1.3$ billion, respectively, in expanding charging infrastructure since 2019 alone (Smith 2019). Retailers and real estate developers are important drivers too. For example, one major shopping mall developer in Japan finances charging stations within its sites' parking facilities and offers shoppers store credits in exchange for drawing on the electricity stored in their EV batteries to power the mall during periods of high energy demand (EV100 2021). Meanwhile, public grants, rebates, partnerships, and tax incentives can critically enable and bolster private sector investments to ensure that charging infrastructure parallels and accommodates rapidly growing EV demand. For instance, the current phase of India's FAME scheme extends capital grants to private companies to build and maintain public EV charging infrastructure on 18 major highways (Shannon and Abadie 2021).

Prioritize decarbonizing buses and freight fleets. Electric buses have the dual benefit of improving equal access for all and reducing operating expenditures. Bloomberg estimates that the total cost of operating and maintaining electric buses is cheaper than conventional diesel buses, assuming the bus drives at least 80 to 170 kilometers a day, depending on the size of the battery 


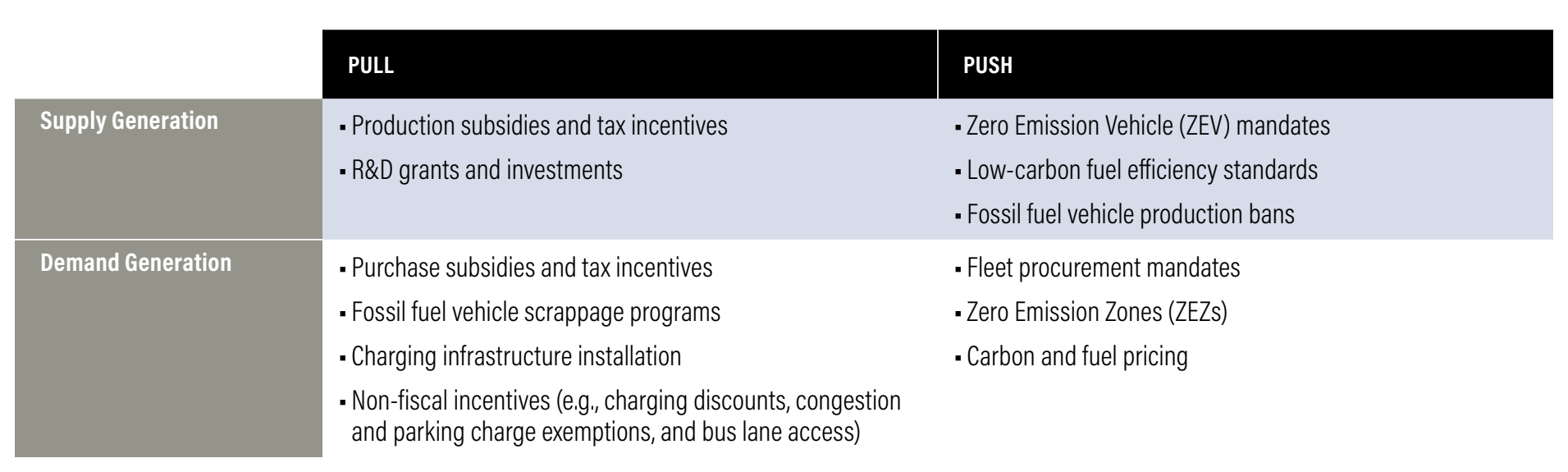

Source: Authors, adapted from Axsen et al. (2020).

(BNEF 2018). Santiago, Chile, with 776 electric buses (e-buses), has the largest e-bus fleet outside China, including 150 ordered this year (C40 2020a). Santiago achieved this through partnerships and fiscal contracts with utility companies, bus manufacturers, and individual operators that helped mitigate upfront costs. One city bus company found that operational and maintenance costs were 70 percent and 37 percent cheaper, respectively, than those of its former diesel buses. These cost savings could free up resources for transit agencies to improve services, construct transit infrastructure, and build resilience during times of crisis or low demand (Kothari and Sclar 2020).

Decarbonizing freight fleets is essential. Under current freight trends, global demand for goods will more than triple by 2050, with logistics emissions doubling during the same time frame (ITF 2019). Decarbonizing this sector requires an integrated approach, which includes optimizing logistics, managing demand, and decarbonizing lightand heavy-duty freight fleets. For instance, a study from the World Economic Forum found that an urban freight strategy integrating electric light-duty delivery vehicles, off-hour deliveries, parcel lockers, and dynamic routing and load-pooling could avoid 30 percent of local freight emissions, reduce carrier cost by 25 percent, and decrease congestion by 30 percent by 2030 (WEF 2020). These new vehicles should also include advanced safety systems, like intelligent speed management and high-visibility cabins, that benefit the safety of drivers and vulnerable road users.

\section{Opportunity \#4: Shift People and Goods to Rail}

\section{Finding:}

Rail is a prominent item in several countries' past and current economic recovery programs. These investments are not innately green. For instance, Chinese rail investments after the 2008 Great Financial Recession benefited the regional transport of coal and may have indirectly led to short-term emission increases (Jaeger et al. 2020). However, rail investments can hold both long-term environmental and economic value when they shift transport from more energy intensive passenger and freight modes, such as short-distance aviation and long-distance vehicle travel (IEA 2019b). Under these conditions, rail can also improve local air quality, economic conditions, and both inter- and intracity access.

\section{Action areas:}

Expand urban and interurban passenger rail. Like many large, complex infrastructure projects, rail requires hefty initial investments and longer time frames, but it can have many economic benefits. In London, a $£ 15$ billion ( $\$ 19.8$ billion) investment in urban rail would increase financial and business service employment density by 1.8 percent and 5.9 percent, respectively (Graham and Van Dender 2009). In China, several studies find that cities with high-speed rail network links have greater boosts in local GDP and tourism, reduced traffic fatalities on highways, and higher economic growth than those without (Li et al. 2018; Lawrence et al. 2019; Li et al. 2020). In lieu of high-speed rail, simply reintroducing passenger service on existing rail lines, increasing frequency, or improving 
the quality of existing inter- and intracity lines can make positive impacts, particularly in countries with underutilized rail networks. The emission reduction potential increases further when paired with train electrification and grid modernization.

Invest in and electrify freight rail. The mode-share of domestic and international shipped goods has been increasing in the direction of road for high-volume goods, and air for high-value goods, at the expense of more energy-efficient rail and waterborne modes. A reversal of this trend could mitigate both GHG emissions and local pollutants. If growth in global truck travel between 2010 and 2050 could be cut by half from the projected 70 percent and shifted to expanded rail systems, fuel demand and $\mathrm{CO}_{2}$ could be reduced by about 20 percent with only about a fifth of this savings being offset by increased rail energy use (Sims et al. 2014). Cities in China and India have experimented with shifting commercial goods from trucks to rail and have observed reductions in local air pollution and climate emissions (Fried et al. 2020; Kalia and Maiti 2021). Moreover, rail expansions can leverage different public-private partnerships, such as railroad and railcar-sharing and other franchise agreements (World Bank 2020b).

\section{Opportunity \#5: Fund Clean R\&D and a Just Transition}

\section{Finding:}

Economic recovery packages offer an opportunity to mitigate emissions in "harder-to-abate" sectors that require next generation zero-emission fuels and technologies. Zero-emission and fuel efficiency technologies to decarbonize heavy-duty freight, aviation, and maritime exist, but further research and development from policymakers, companies, and capital investors will be essential to accelerating market adoption, lowering upfront price barriers, and reducing the environmental footprint of downstream supply chains (ETC 2018). Clean R\&D is also a politically popular area for stimulus investments. In a survey of 231 central bank officials, finance ministry officials, and other economic experts, an Oxford University study identified clean R\&D spending as having the highest overall support and perceived climate mitigation potential (Hepburn et al. 2020). Ushering in new zero-emission industries can help create jobs and improve livelihoods, but only through a just transition that prioritizes workforce training and education.

\section{Action areas:}

\section{Increase demand for and lower costs of the next generation of zero-emission fuels through national policy strategies and clean research and development. Zero-emission fuel cells, like hydrogen,} and other fuel efficiency measures may show promise to decarbonize heavy and long-distance transport modes, like intercity buses, rail, and long-haul freight, maritime shipping, and aviation in the mid to long term (ETC 2018; Jackson 2020; ICCT 2020). However, further evidence is needed to fully understand the environmental impacts and scalability of these improvements. Countries, cities, and companies must set clear targets and invest in clean $\mathrm{R} \& \mathrm{D}$ to increase market adoptability and commercial demand for zero- and low-carbon emission transport solutions (IEA 2019a).

Transition workers to a green, digital economy. Since green jobs come at the expense of jobs lost in fossil fuel and carbon-intensive industries, governments, academic institutions, and companies must institute comprehensive measures for vocational training to improve skill transferability, ensure social inclusion, and strengthen livelihoods (OECD 2020a). An analysis of the 2009 American Recovery and Reinvestment Act, which disbursed more than $\$ 700$ million to green workforce training, found the correlation between stimulus spending and employment growth stronger in geographies in which green workforce training funds were disbursed (Chen et al. 2020b). The European Union's Green Deal incorporates a "Just Transition Mechanism," which mobilizes €100 billion ( $\$ 123$ billion) in funds that include provisions for workforce-reskilling programs, better access to loans for green start-ups and social enterprises, improved digital connectivity, and the creation of new green jobs (European Commission 2020).

\section{RAISING AMIBITION FOR COP26}

In November 2021 the United Kingdom will host the 26th UN Climate Change Conference of the Parties (COP26). COP26 is significant as it will be the first COP to take place after the landmark Paris Agreement's measures took effect and the first opportunity since then for nations to come together to review national commitments and strengthen ambition. There is great potential to align ongoing green recovery programs with the raised ambition sought in countries' nationally determined contributions. The United Nations is now asking countries to raise ambition in their NDCs. NDCs are global commitments to deliver 
progress toward the goals of the Paris Agreement. Among other traits, they address a long-term target, updated every five years, create a policy context to steer investments, and attract climate finance and investment (Waskow et al. 2020). According to Climate Action Tracker, and additional input from WRI experts, 64 countries, representing over half of global climate emissions, have announced net-zero targets (WRI 2020).

Bold climate action is not confined to national governments. Currently 10,932 cities and regions, primarily from developed countries, are recording climate actions on the Global Climate Action portal, more than three times the number only four years ago (Lebling et al. 2020). Companies are acting too. As of January 2021, 4,302 businesses and 1,114 investors had committed to achieving net-zero carbon emissions by 2050 through the Race to Zero global campaign (UNFCCC 2020). Multilateral development banks and international finance institutions play a dual role in helping low-income countries alleviate debt, an emergent crisis as the global economy recovers from the pandemic and interest rates rise, while simultaneously advancing climate adaption and mitigation investments (Wheatley 2021). The World Bank and International Monetary Fund are launching a platform to help low-income countries tackle debt relief and climate change during COP26 (Shalal 2021).

Not all recovery measures link to climate mitigation or adaptation, as they are shorter-term investments to spur economic and sustainable growth. Despite this, green recovery and NDC enhancement can play complementary roles in building a green, resilient, and inclusive future (Waskow et al. 2020). Considered as a building block in a larger climate policy structure, green recovery provides some of the necessary near-term foundation for NDCs. While green recovery measures may fit into current or enhanced NDCs, they also may help enhance transport sector NDCs in a way that previously was not considered (see Figure 9).

Figure 9 | Green transport building blocks approach

2050 OUTCOMES

2030 GOALS

MEDIUM-TERM
MEASURES

IMMEDIATE
STIMUUUS
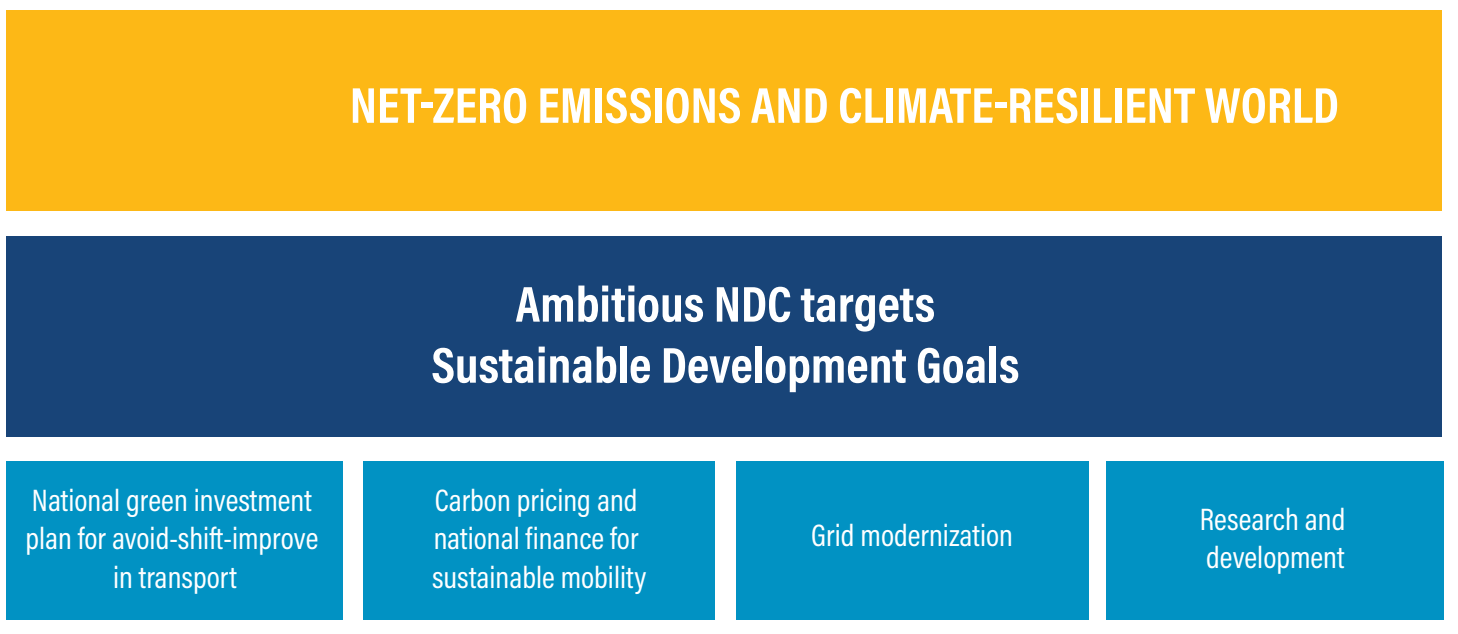

Bicycle and

pedestrian

infrastructure

Ambitious NDC targets Sustainable Development Goals
Carbon pricing and

national finance for

sustainable mobility

Public transport liquidity

infrastructure, and

integration

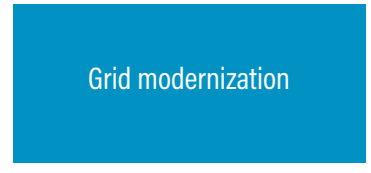

Avoid vehicle travel

through limited

highway spending
Research and

development

Note: $\mathrm{NDC}=$ nationally determined contribution.

Source: Authors, based on Waskow et al. (2020). 


\section{CONCLUSION: A BETTER "NEW NORMAL"}

\section{FOR TRANSPORT?}

COVID-19 disrupted mobility to magnitudes unseen in recent memory. This paper outlines how countries, cities/ regions, and companies have reacted not only to ensure that transport services remain accessible and affordable to everyone but also to center decarbonization as a key strategy for moving forward. However, as we transition away from this notion of economic recovery to a "new normal," we are left with open questions about how to reach a better equilibrium.

Will we go beyond bare-minimum public transport stabilization and on to proactive measures that improve service quality, affordability, and resilience? Can we carry forward today's kinetic energy around active transport, turning pop-up bike lanes and sidewalks into safe, permanent spaces for pedestrians and cyclists? How will public and corporate momentum build around EVs, charging infrastructure, and next-generation zero-emission fuels and technologies, from airplanes and ships to cars and trucks? Amid the meteoric rise of home deliveries, with the vulnerabilities of our global supply chains laid bare, how will public and private sectors come together to decarbonize freight and introduce new digital technologies and data to improve supply chain efficiency and resiliency?
While this paper reviews some best practices that are shaping green recovery and sustainable transport across several key action areas, long-term GHG emissions savings can be counteracted by global fossil fuel investments and subsidies. Further research needs to evaluate and quantify the extent to which green transport and energy investments can help achieve long-term outcomes of net-decarbonization, economic recovery, improved health, and social equity. 


\section{APPENDIX A: EXTENDED METHODOLOGY AND EXPLORATORY ANALYSIS}

This report analyzes data from Energy Policy Tracker to serve as a baseline for understanding how governments have implemented transport spending within stimulus packages. Energy Policy Tracker is a database maintained by a consortium of 14 research institutions that tracks global fiscal policy responses to the pandemic. While several stimulus trackers exist (those of the Rhodium Group, Carbon Brief, and International Monetary Fund, among others), we found Energy Policy Tracker to be the most complete, with quantified funds, detailed policy descriptions, and sources. We also found it to be the easiest to access, with the option to download data in a commaseparated values format.

However, it is important to note the tool's limitations. According to its website, Energy Policy Tracker captures only 3-5 percent of total stimulus commitments. Policies not related to energy, such as unemployment support, are not included; additionally, nonmonetary policies, such as tax relief or adjusted emission standards, may not be captured or quantified. of the 922 stimulus policies tracked, 323 policies did not quantify or announce monetary commitments. Therefore, funds identified by Energy Policy Tracker do not represent all national or subnational policies and stimulus committed to environmentally relevant sectors. Energy Policy Tracker data should

\section{be considered as a useful sample to help broadly evaluate how governments are (or are not) prioritizing decarbonization in their stimulus spending.}

This report analyzes all stimulus packages from Energy Policy Tracker with the "mobility" sector tag, with additional policies reclassified from the "multiple sectors" tag when relevant. Our analysis draws on the data available in February 2021. Mobility sector stimulus accounts for 266 tracked policies, of which 219 have quantified or announced monetary commitments, representing a collective sum of $\$ 298$ billion (see Figures $A 1$ and $A 2$ ).

Within transport-related stimulus, we identified the 10 following major areas of investment, in order of highest quantity of funds committed (see Figure A3):

- Gray aviation and maritime support: We classify all investments in the aviation and, to a lesser degree, the maritime sector as "gray" when they do not have any environmental conditions or provisions to decarbonize the sector. Most investments in this area compensate corporate airlines for lost revenues, with some investments that support airport, seaport, and cruise-line operations.

Figure A1 | Breakdown of transport-related stimulus spending by country and investment area (USȘ billions)

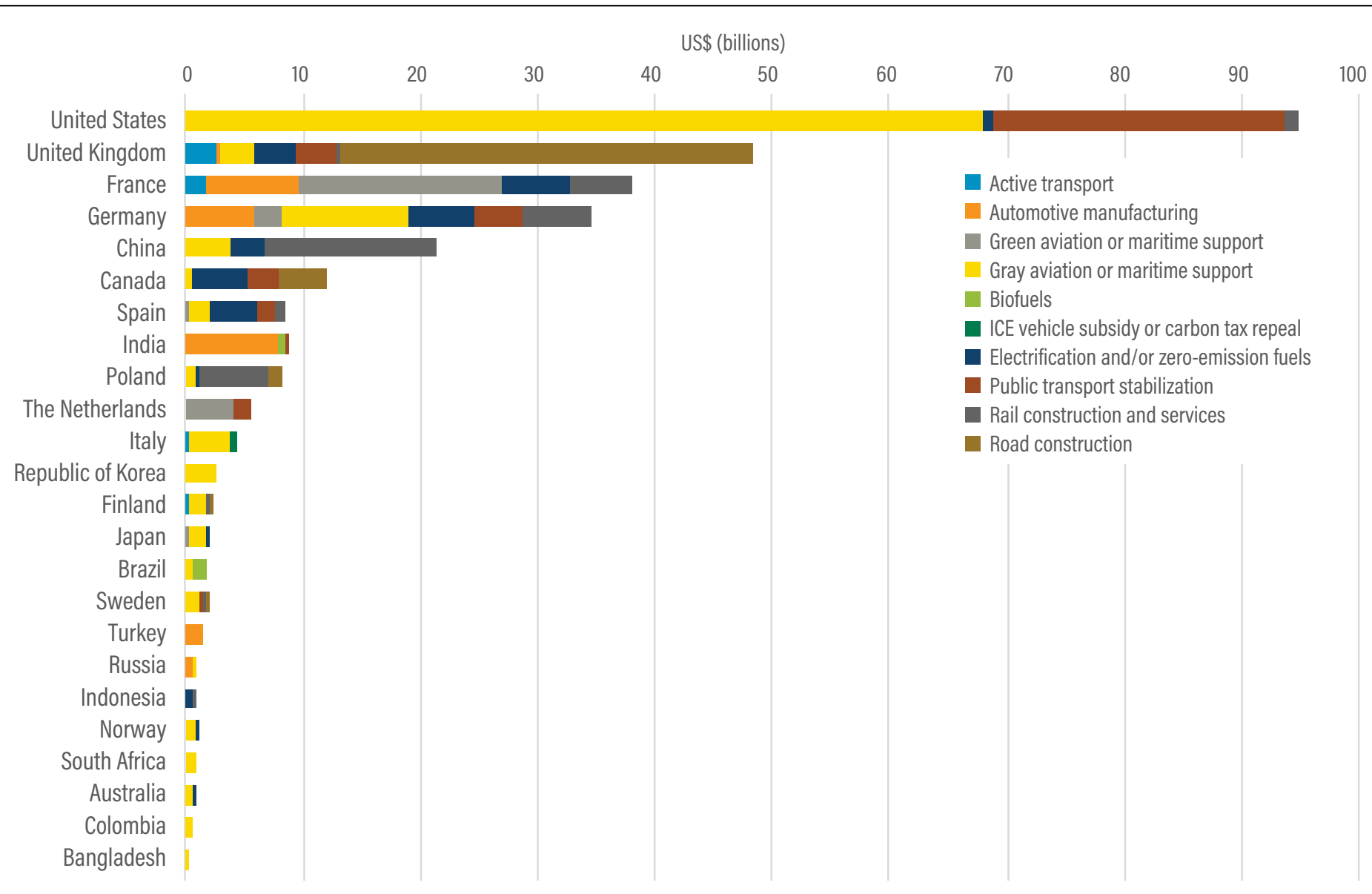


Figure A2 | Breakdown of transport-related stimulus spending by country and investment area (number of quantified and unquantified policies)

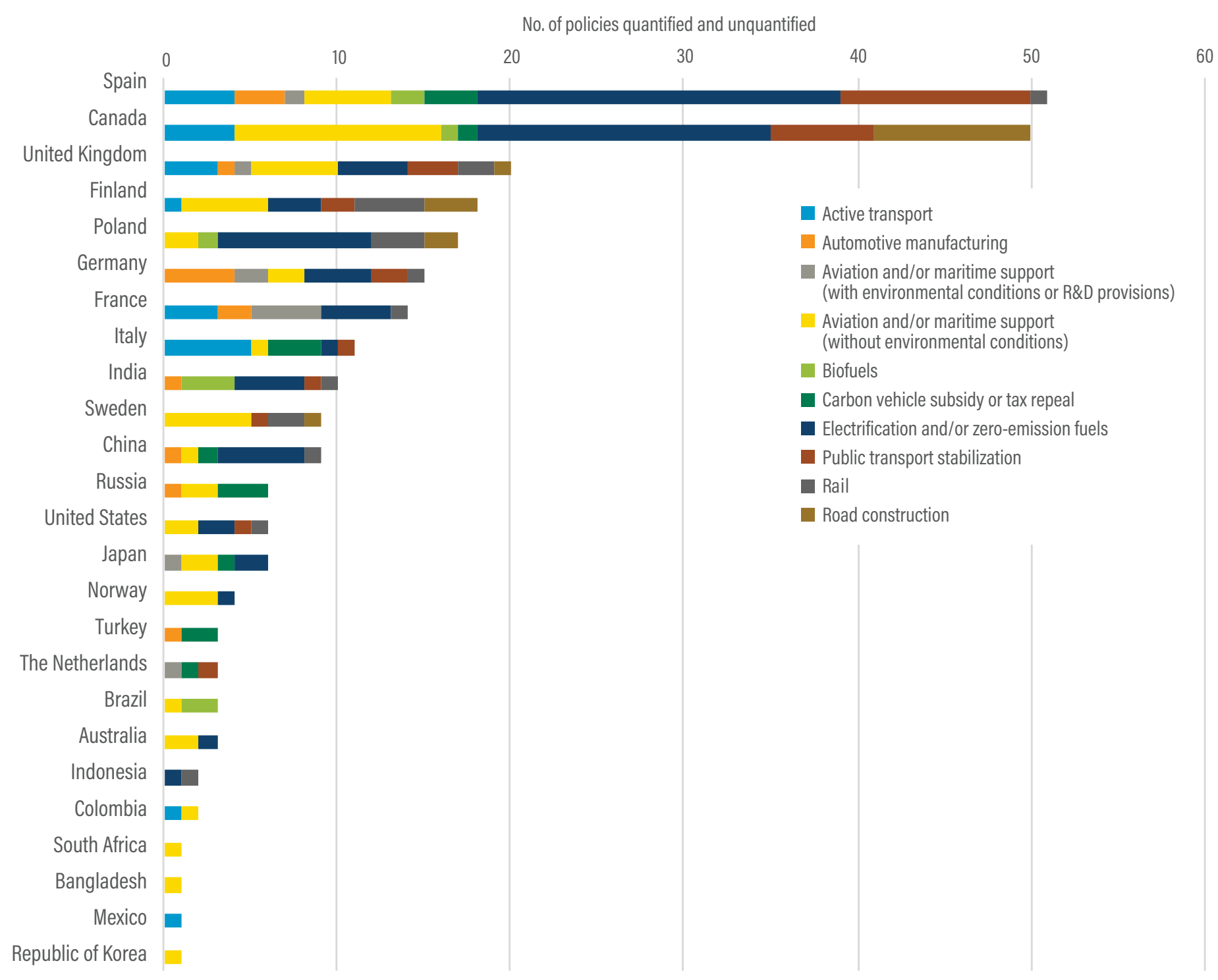

Note: ICE = internal combustion engine; R\&D = research and development.

Source: WRI analysis via Energy Policy Tracker, February 2021.

- Road construction: These are investments in car-oriented road infrastructure construction and repair in both urban and rural areas. According to Energy Policy Tracker data, the United Kingdom announced the highest quantity of road investments (88 percent), through the country's five-year roadbuilding and repair program.

- Public transport stabilization: These investments stabilize agency liquidity, service operations, and worker livelihoods. It is important to note the predominance of the United States in this area. The U.S. Coronavirus Aid, Relief, and Economic Security (CARES) Act, enacted in April 2020, allocated $\$ 25$ billion to stabilize public transport, accounting for 63 percent of all funds committed to public transport. Energy Policy Tracker does not include the additional \$14 billion for U.S. public transport announced in January 2021.

- Rail construction and services: These investments build new rail lines or support operations that transition travel away from carbonintensive, long-distance passenger and goods travel to more energyefficient rail travel.

- Electrification and zero-emission fuels: These investments support the shift to low- and zero-carbon vehicles, including private vehicles and public and commercial fleets. Initiatives include subsidies and tax 
Figure A3 | Breakdown of transport-related stimulus spending by investment area (US\$̦ billions)

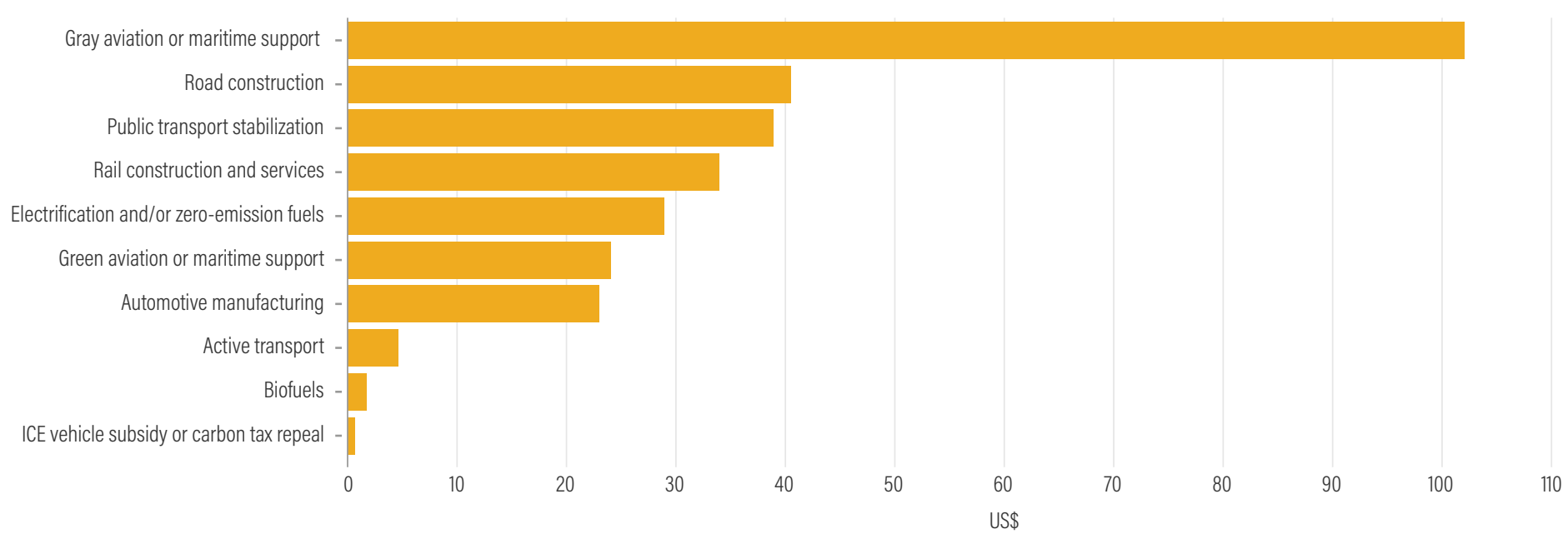

Note: ICE = internal combustion engine.

Source: WRI Analysis via Energy Policy Tracker, Feb 2021.

rebates for electric vehicle (EV) purchases, electric bus procurement, charging infrastructure installation, manufacturer bailouts with EV mandates, and research and development (R\&D) grants and loans for next-generation fuels, such as hydrogen.

- Green aviation and maritime support: As opposed to gray investments, green aviation and maritime investments primarily include bailouts with environmental strings attached, provisions for clean R\&D that could accelerate the adoption of carbon-neutral air and sea vessels, and initiatives to decarbonize port operations.

- Automotive manufacturing: These investments help stabilize lost revenues within the automotive manufacturing sector and related downstream industries. These investments prioritize internal combustion engine (ICE) vehicle assembly or are indifferent to climate goals. However, in some cases, such as in Italy, the government announced provisions to incentivize or mandate EV manufacturing but did not set targets, enforcement mechanisms, and/or quantify funds to achieve such ends.

- Active transport: These investments support infrastructure and initiatives that promote walking, bicycling, and road safety. While seemingly low, Energy Policy Tracker does not capture investments made on the city level, where local governments have spearheaded active mobility responses to COVID-19. Moreover, active transport infrastructure investments tend to require less upfront capital compared to road-only or other public works projects.

- Biofuels: These investments help boost production of biorenewable energy, such as ethanol, either through direct subsidy or mandating of increased fuel blends.

- ICE vehicle subsidy or carbon tax repeal: These investments incentivize the uptake of conventional ICE vehicles, either by reducing carbon taxes or subsidizing new and secondhand vehicle purchases (e.g., car scrappage schemes with weak emission-standard requirements). Policies related to emission standards and carbon taxes are hard to quantify in financial terms; and indeed, Energy Policy Tracker did not include countries like the United States and China that peeled back vehicle emission standards. Therefore, we suspect these policies are underrepresented in the database.

To determine the proposed opportunities and action areas that help countries, cities, and companies shape green recovery through transport, we create a conceptual framework supported by literature on sustainable recovery and transport (overview on $p .11$ ). To simplify classification, we develop two broad categories of stimulus and policy responses. "Green" investments are those with high potential to achieve climate emission targets, create net-positive jobs, and support other sustainability co-benefits (e.g., road safety, health, equity, and air quality). "Gray" investments are either less optimal or counteractive to achieving these goals. On a global level, gray transport-related investments outweigh green investments by about 28 percent. However, some countries stand out in prioritizing green transport investments, which provide illustrative examples to help steer future policies across countries and transport sectors (overview on p. 15). This paper draws its conclusions from today's green transport-related investments and extrapolates solutions for the future. Table A1 gives an overview of the qualitive reasoning used to derive these classifications and subsequent opportunity and action areas. This paper provides a useful, high-level framing that can help public and private stakeholders understand transport's role in a sustainable recovery and adapt solutions. However, the solutions offered are qualitatively linked to sustainability, and more research is needed to quantify the environmental and economic impacts of proposed transport-related recovery solutions. 


\begin{tabular}{|c|c|c|c|}
\hline & $\begin{array}{l}\text { IMPLICATIONS } \\
\text { FOR SUSTAINABLE } \\
\text { RECOVERY }\end{array}$ & EXPLANATION/NOTES & OPPORTUNITY AND ACTION AREA \\
\hline \multirow[t]{3}{*}{ Active transport } & \multirow[t]{3}{*}{ Green } & $\begin{array}{l}\text { Walking and bicycling infrastructure promote zero- } \\
\text { emission and healthier travel modes. }\end{array}$ & $\begin{array}{l}\text { Accelerate current global efforts to expand active } \\
\text { mobility infrastructure. }\end{array}$ \\
\hline & & $\begin{array}{l}\text { U.S.-based studies found that on a per-dollar basis, } \\
\text { building active transport infrastructure creates more } \\
\text { jobs (direct, indirect, and induced) than car-only road } \\
\text { infrastructure. }\end{array}$ & \multirow[t]{2}{*}{$\begin{array}{l}\text { Ensure long-term project sustainability by establishing } \\
\text { national-level finance and governance. }\end{array}$} \\
\hline & & $\begin{array}{l}\text { When implementing a safe systems approach, a } \\
\text { walkable and bikeable city reduces road crashes and } \\
\text { fatalities. }\end{array}$ & \\
\hline \multirow[t]{2}{*}{$\begin{array}{l}\text { Automotive } \\
\text { manufacturing }\end{array}$} & \multirow[t]{2}{*}{ Gray } & $\begin{array}{l}\text { Automotive manufacturing, and related sectors, is a } \\
\text { major employer worldwide, especially in middle- and } \\
\text { low-income countries. }\end{array}$ & \\
\hline & & $\begin{array}{l}\text { While supporting these jobs is important, without } \\
\text { provisions to transition to electric and zero-emission } \\
\text { vehicles, investments in this sector may enforce } \\
\text { status quo transport emission levels, congestion, and } \\
\text { pollution. }\end{array}$ & \\
\hline \multirow[t]{4}{*}{$\begin{array}{l}\text { Green aviation or } \\
\text { maritime support }\end{array}$} & \multirow[t]{4}{*}{ Green } & $\begin{array}{l}\text { Aviation and maritime is another important job sector } \\
\text { in need of support. }\end{array}$ & \multirow{4}{*}{$\begin{array}{l}\text { Invest in clean research and development (R\&D) and } \\
\text { just transition mechanisms that accelerate zero- } \\
\text { emission market adoption and industries. }\end{array}$} \\
\hline & & $\begin{array}{l}\text { However, these sectors are on track to be a major } \\
\text { emissions culprit. }\end{array}$ & \\
\hline & & $\begin{array}{l}\text { While zero-emission solutions exist, market adoption } \\
\text { rates within this sector (often labeled "harder-to- } \\
\text { abate") are slower than other transport sectors (e.g., } \\
\text { light-duty vehicles). }\end{array}$ & \\
\hline & & $\begin{array}{l}\text { Investments to accelerate zero-emission technology } \\
\text { adoption can have the dual benefit of supporting } \\
\text { sector jobs and decarbonization. }\end{array}$ & \\
\hline $\begin{array}{l}\text { Gray aviation or } \\
\text { maritime support }\end{array}$ & Gray & $\begin{array}{l}\text { Investments in this sector without environmental } \\
\text { conditions or clean R\&D provisions may reenforce the } \\
\text { sector's current emission levels, or even worsen them. }\end{array}$ & \\
\hline \multirow[t]{2}{*}{ Biofuels } & \multirow[t]{2}{*}{ Gray } & $\begin{array}{l}\text { In some instances, biofuels are a short-term } \\
\text { solution to reduce carbon emissions and fossil fuel } \\
\text { dependency. }\end{array}$ & \\
\hline & & $\begin{array}{l}\text { However, stimulus investments in this area are limited, } \\
\text { and fuel crops may compete for land and water, } \\
\text { indirectly increase emissions, displace food crops, } \\
\text { and/or encourage deforestation. Therefore, we do not } \\
\text { advocate for biofuels in this paper. }\end{array}$ & \\
\hline
\end{tabular}




\begin{tabular}{|c|c|c|c|}
\hline & $\begin{array}{l}\text { IMPLICATIONS } \\
\text { FOR SUSTAINABLE } \\
\text { RECOVERY }\end{array}$ & EXPLANATION/NOTES & OPPORTUNITY AND ACTION AREA \\
\hline $\begin{array}{l}\text { Internal } \\
\text { combustion } \\
\text { engine vehicle } \\
\text { subsidy or carbon } \\
\text { tax repeal }\end{array}$ & Gray & $\begin{array}{l}\text { Incentivizing car purchases (e.g., car scrappage, } \\
\text { tax rebates) without mechanisms to ensure lower } \\
\text { emission levels has an obvious negative climate } \\
\text { impact. } \\
\text { There is also limited evidence that these schemes } \\
\text { create jobs in the automotive sector. Often, incentives } \\
\text { move new vehicle purchases up in time rather than } \\
\text { create new demand. }\end{array}$ & \\
\hline $\begin{array}{l}\text { Electrification } \\
\text { and/or zero- } \\
\text { emission fuels }\end{array}$ & Green & $\begin{array}{l}\text { Electrification and other emerging zero-emission fuels } \\
\text { will be essential to decarbonizing the transport sector. } \\
\text { To accelerate market adoption to ensure the transport } \\
\text { sector will achieve a } 2050 \text { net-zero emission target, } \\
\text { additional policy and fiscal action from government is } \\
\text { essential. } \\
\text { Jobs can be created within the electric vehicle } \\
\text { space-especially in the installation of public charging } \\
\text { infrastructure. } \\
\text { Zero tailpipe emissions also mitigate local air pollution. }\end{array}$ & $\begin{array}{l}\text { Adapt and blend policy solutions that "push" and "pull" } \\
\text { electrification. } \\
\text { Install public charging infrastructure. } \\
\text { Decarbonize bus and commercial fleets. }\end{array}$ \\
\hline $\begin{array}{l}\text { Public transport } \\
\text { stabilization }\end{array}$ & Green & $\begin{array}{l}\text { Public transport investments create and sustain more } \\
\text { jobs than investments such as highways. } \\
\text { Both stabilizing and investing in the long-term } \\
\text { recovery and prosperity of public transport also } \\
\text { improves equal access to jobs and services, improves } \\
\text { road safety, supports smart urban growth, and limits } \\
\text { carbon emissions. }\end{array}$ & $\begin{array}{l}\text { Stabilize public transport operations and liquidity } \\
\text { through emergency funds first. } \\
\text { Strengthening services for the long run requires that } \\
\text { transit stakeholders reimagine governance, finance, } \\
\text { priority infrastructure, data, and modal integration, } \\
\text { among other transformations. }\end{array}$ \\
\hline $\begin{array}{l}\text { Rail construction } \\
\text { and services }\end{array}$ & Green & $\begin{array}{l}\text { Rail investments have long-term value, both } \\
\text { environmental and economic, when they result in } \\
\text { shifts from more energy-intensive passenger and } \\
\text { freight modes. } \\
\text { Under these conditions, rail can also improve local } \\
\text { air quality, economic conditions, and both inter- and } \\
\text { intracity access. }\end{array}$ & $\begin{array}{l}\text { Expand and electrify urban and intercity rail (both } \\
\text { freight and passenger), but ensure that a shift away } \\
\text { from vehicle and air travel is a primary objective. }\end{array}$ \\
\hline Road construction & Gray & $\begin{array}{l}\text { Roadbuilding projects require high upfront } \\
\text { investments in land acquisition and are slow to } \\
\text { disburse funds, making them a less effective driver } \\
\text { of job creation than other transport investments (e.g., } \\
\text { public transport). } \\
\text { While in rural settings, paving and weatherizing roads } \\
\text { may help improve access to essential services and } \\
\text { goods, in urban settings, they contribute to traffic } \\
\text { congestion, emissions, pollution, and crashes. }\end{array}$ & \\
\hline
\end{tabular}


1 After the analysis for this paper was completed, the United States passed the American Rescue Plan Act of 2021, which committed additional support to public transport agencies.

\section{REFERENCES}

Abubaker, I., J. Tuniz, and A. Oursler. 2020. "As the Coronavirus Looms, Can African Cities Become More Walkable and Bikeable?" TheCityFix (blog), August 12. https://thecityfix.com/blog/coronavirus-looms-can-african-citiesbecome-walkable-bikeable-iman-abubaker-janene-tuniz-anna-oursler/.

Akrofi, M.M., and S.H. Antwi. 2020. "COVID-19 Energy Sector Responses in Africa: A Review of Preliminary Government Interventions." Energy Research \& Social Science 68 (0ctober): 101681. doi:10.1016/j.erss.2020.101681.

Anenberg, S., J. Miller, D. Henze, and R. Minjares. 2019. "A Global Snapshot of the Air Pollution-Related Health Impacts of Transportation Sector Emissions in 2010 and 2015." International Council on Clean Transportation. https:// theicct.org/sites/default/files/publications/Global_health_impacts_ transport_emissions_2010-2015_20190226.pdf.

APTA (American Public Transport Association), 2020. "Economic Impact of Public Transportation Investment." https://www.apta.com/wp-content/ uploads/APTA-Economic-Impact-Public-Transit-2020.pdf.

Argus Media. 2020a. "New Delhi Supports Indian EV Market after Covid-19 Hit." August 11. https://www.argusmedia.com/en/news/2131325-new-delhisupports-indian-ev-market-after-covid19-hit.

Argus Media. 2020b. "China Targets Big Expansion of High-Speed Rail Network." August 21. https://www.argusmedia.com/en/news/2134482-chinatargets-big-expansion-of-highspeed-rail-network.

Axsen, J., P. Plötz, and M. Wolinetz. 2020. "Crafting Strong, Integrated Policy Mixes for Deep CO Mitigation in Road Transport." Nature Climate Change 10 (9): 809-18. doi:10.1038/s41558-020-0877-y.

Bannon, E. 2020. "Air France's Bailout 'Climate Conditions' Explained." Transport \& Environment (blog), June 3. https://www.transportenvironment. org/publications/air-frances-bailout-climate-conditions-explained.

Barry, K. 2010. "To Create Jobs, Build Public Transit, Not Highways." Wired, January 21. https://www.wired.com/2010/01/jobs-for-main-street-act/.

Bauer, W., 0. Riedel, and F. Herrmann. 2020. "Employment 2030: Effects of Electric Mobility and Digitalisation on the Quality and Quantity of Employment at Volkswagen." Stuttgart, Germany: Fraunhofer Institute for Industrial Engineering (IAO). https://www.iao.fraunhofer.de/content/dam/ iao/images/iao-news/employment-2030-summary.pdf.

Bellis, R. 2020. "What Service Cuts Are Transit Agencies Facing around the Country?" Transportation for America (blog), December 1. https://t4america. org/2020/12/01/what-service-cuts-are-transit-agencies-facing-around-thecountry/.

Berg, J., F. Bonnet, and S. Soares. 2020. "Working from Home: Estimating the Worldwide Potential." VoxEU (blog), May 11. https://voxeu.org/article/workinghome-estimating-worldwide-potential.
Bliss, L. 2019. "To Build a Better Bus Lane, Just Paint It." Bloomberg CityLab, March 1. https://www.bloomberg.com/news/articles/2019-03-01/howtactical-transit-lanes-help-buses-beat-traffic.

Bliss, L., J.C.F. Lin, and M. Patino. 2020. "Pandemic Travel Patterns Hint at Our Urban Future." Bloomberg CityLab, June 18. https://www.bloomberg.com/ graphics/2020-coronavirus-transportation-data-cities-traffic-mobility/.

Bloomberg News. 2020. "China's Rethink on Car Pollution May Signal a Retreat on Climate." March 18. https://www.bloomberg.com/news/ articles/2020-03-18/china-s-rethink-on-car-pollution-may-signal-a-retreaton-climate.

BNEF (Bloomberg New Energy Finance). 2018. "Electric Buses in Cities Driving towards Cleaner Air and Lower $\mathrm{CO}_{2}$." https://c40-production-images. s3.amazonaws.com/other_uploads/images/1724_BNEF_C40_Electric_ buses_in_cities_FINAL_APPROVED.original.pdf?1523349304.

BNEF. 2020. EVO Report 2020. New York: BNEF, https://about.bnef.com/ electric-vehicle-outlook/.

Brownson, R.C., T.K. Boehmer, and D.A. Luke. 2005. "Declining Rates of Physical Activity in the United States: What Are the Contributors?" Annual Review of Public Health 26 (1): 421-43. doi:10.1146/annurev. publhealth.26.021304.144437.

C40. 2014. "C40 Climate Action in Megacities." https://issuu.com/c40cities/ docs/c40_climate_action_in_megacities/11.

C40. 2019. "Toward a Healthier World: Connecting the Dots between Climate, Air Quality and Health." https://www.c40knowledgehub.org/s/article/ Toward-a-Healthier-World-Connecting-the-dots-between-climate-airquality-and-health?language=en_US.

C40. 2020a. "Metbus Pioneering E-bus Deployments in Santiago," https:// www.c40knowledgehub.org/s/article/Metbus-pioneering-e-busdeployments-in-Santiago?language=en_US.

C40. 2020b. Technical Report: The Case for a Green and Just Recovery. London: C40. https://c40.my.salesforce.com/sfc/p/\#36000001Enhz/a/100000 00gRCH/240gSbRwj1hZ305yJbyPMZJQKhXXWNYE8k8sr2ADsi8.

Cattaneo, L. 2018. Investing in Charging Infrastructure for Plug-In Electric Vehicles. Washington, DC: Center for American Progress. https://www. americanprogress.org/issues/green/reports/2018/07/30/454084/investingcharging-infrastructure-plug-electric-vehicles/.

Ceres, n.d. "Corporate Electric Vehicle Alliance." https://www.ceres.org/ our-work/transportation/corporate-electric-vehicle-alliance. Accessed April 9, 2021.

Chen, K., M. Wang, C. Huang, P.L. Kinney, and P.T. Anastas. 2020a. "Air Pollution Reduction and Mortality Benefit during the COVID-19 Outbreak in China." Lancet Planetary Health 4 (6): e210-12. doi:10.1016/S2542-5196(20)30107-8.

Chen, Z, G. Marin, D. Popp, and F. Vona. 2020b. "Green Stimulus in a Post-pandemic Recovery: The Role of Skills for a Resilient Recovery." Environmental and Resource Economics 76 (4): 901-11. doi:10.1007/s10640020-00464-7. 
Cities4Health. 2020. "Expanding Cycling Infrastructure to Fight COVID-19 Pandemic: Lima, Peru." https://cities4health.org/assets/library-assets/ lima_final_oct-2020.pdf

Combs, T., and C.F. Pardo, 2021. "Shifting Streets COVID-19 Mobility Data: Findings from a Global Dataset and a Research Agenda for Transport Planning and Policy." Transportation Research Interdisciplinary Perspectives 9 (March): 100322. doi:10.1016/j.trip.2021.100322.

CUT (Coalition for Urban Transitions). 2019. Climate Emergency, Urban Opportunity. Washington, DC: CUT. https://urbantransitions.global/wpcontent/uploads/2019/09/Climate-Emergency-Urban-Opportunity-report.pdf.

Cyclescheme. 2021. "The UK's Most Popular Cycle to Work Benefit." https:// www.cyclescheme.co.uk/.

Dalkmann, $\mathrm{H}_{\mathrm{.}}$ and C. Brannigan. 2007. Transport and Climate Change. Module 5e: Sustainable Transport: A Sourcebook for Policy-Makers in Developing Cities. Eschborn, Germany: Gesellschaft für technische Zusammenarbeit (GTZ).

Dasgupta, S. 2020. "India Awards First Contract on \$3.3B High-Speed Rail." Engineering News Record, November 17. https://www.enr.com/ articles/50754-india-awards-first-contract-on-33b-high-speedrail? $\mathrm{v}=$ preview.

de Blas, I., M. Mediavilla, I. Capellán-Pérez, and C. Duce. 2020. "The Limits of Transport Decarbonization under the Current Growth Paradigm." Energy Strategy Reviews 32 (November): 100543. doi:10.1016/j.esr.2020.100543.

Dingel, J.I., and B. Neiman. 2020. "How Many Jobs Can Be Done at Home?" NBER Working Paper Series, no, w26948. Cambridge, Mass: National Bureau of Economic Research.

Dunn, K. 2020. "Climate Conditions on Airline Government Bailouts Are Rareand the Coronavirus Likely Won't Be an Exception." Fortune, June 26. https:// fortune.com/2020/06/26/airline-bailouts-climate-conditions-coronavirus/.

ECF (European Cyclists Federation). 2020، "Cycling beyond the Crisis: COVID-19 Measures Tracker." http://datastudio.google. com/reporting/lae589b4-e01c-4c27-8336-f683ea516256/page/ wkQTB?feature $=0$ pengraph .

Eisenstein, P. 2019. "Rise of EVs Will Cost Jobs across Auto Industry." Detroit Bureau, October 10. https://www.thedetroitbureau.com/2019/10/rise-of-evswill-cost-jobs-across-auto-industry/.

Energy Policy Tracker. 2021. "Track Funds for Energy in Recovery Packages."February. https://www.energypolicytracker.org/.

Engel, $H_{1}$, A. Hamilton, S. Hieronimus, T. Nauclér, D. Fine, D. Pinner, S. Bertreau, et al. 2020. "How a Post-pandemic Stimulus Can both Create Jobs and Help the Climate." McKinsey \& Company. https://www.mckinsey.com/businessfunctions/sustainability/our-insights/how-a-post-pandemic-stimulus-canboth-create-jobs-and-help-the-climate.

ETC (Energy Transitions Commission). 2018. Mission Possible: Reaching NetZero Carbon Emissions from Harder-to-Abate Sectors by Mid-century. London: ETC. https://www.energy-transitions.org/wp-content/uploads/2020/08/ ETC_MissionPossible_FullReport.pdf.
ET Energy World. 2020. "Govt Sanctions 670 Electric Buses, 241 Charging Stations under FAME Scheme." September 25, https://energy.economictimes. indiatimes.com/news/power/govt-sanctions-670-electric-buses-241charging-stations-under-fame-scheme/78312963.

European Commission. 2020. "The Just Transition Mechanism." https:// ec.europa.eu/commission/presscorner/detail/en/fs_20_39.

EV100. 2021. EV100 Progress and Insights Report 2021. London: EV100. https:// www.theclimategroup.org/ev100-annual-report-2021.

Ewing, R., G. Meakins, S. Hamidi, and A.C. Nelson. 2014. "Relationship between Urban Sprawl and Physical Activity, Obesity, and MorbidityUpdate and Refinement." Health \& Place 26 (March): 118-26. doi:10.1016/j. healthplace.2013.12.008.

Flusche, D. 2012. "Bicycling Means Business: The Economic Benefits of Bicycle Infrastructure." League of American Bicyclists, https://bikeleague. org/sites/default/files/Bicycling_and_the_Economy-Econ_Impact_ Studies_web.pdf.

Fortunati, J. 2020. "The CARES Act Isn't Enough to Save Public Transportation." Transportation for America (blog), April 20. https://t4america. org/2020/04/20/the-cares-act-isnt-enough-to-save-public-transportation/.

Frangoul, A. 2020. "Siemens and Deutsche Bahn Plan Trial of HydrogenPowered Train in Germany." CNBC, November 26. https://www.cnbc. com/2020/11/26/siemens-deutsche-bahn-plan-trial-of-hydrogen-poweredtrain.html.

Fransen, T., B. Welle, C. Gorguinpour, M. McCall, R. Song, and A. Tankou. 2019. "Enhancing NDCs: Opportunities in Transport." Working paper. Washington, DC: World Resources Institute.

Fried, T., E. Jackson, B. Welle, and S. Avelleda. 2020. "The Road to ZeroEmission Cities Goes through Freight." TheCityFix (blog), September 15. https://thecityfix.com/blog/the-road-to-zero-emission-cities-goes-throughfreight/,

Garrett-Peltier, H. 2011. "Pedestrian and Bicycle Infrastructure: A National Study of Employment Impacts." Amherst: University of Massachusetts. https://www.peri.umass.edu/publication/item/427-pedestrian-and-bicycleinfrastructure-a-national-study-of-employment-impacts.

George-Parkin, H. 2020. "Home Delivery Has Helped China through Its Coronavirus Crisis. The US Needs to Catch Up." Vox, March 25. https://www. vox.com/the-goods/2020/3/25/21193817/home-delivery-china-coronavirusus-alibaba-amazon.

Google. 2020. "COVID-19 Community Mobility Report." https://www.google. com/covid19/mobility?hl=en.

Gorner, M., and L. Paoli. 2021. "How Global Electric Car Sales Defied Covid-19 in 2020-Analysis." International Energy Agency (blog), January 28. https:// www.iea.org/commentaries/how-global-electric-car-sales-defied-covid19-in-2020.

Gouldson, A., A. Sudmant, H. Khreis, and E. Papargyropoulou. 2019. "The Economic and Social Benefits of Low-Carbon Cities: A Systematic Review of the Evidence." Background paper. Coalition for Urban Transitions, https:// urbantransitions.global/wp-content/uploads/2019/08/CUT2018_CCCEP_final. pdf. 
Government of the Netherlands. 2020. "Minister Van Nieuwenhuizen Imposes Use of Cleaner Fuel in Aviation Sector." March 4, https://www.government. nl/latest/news/2020/03/04/minister-van-nieuwenhuizen-imposes-use-ofcleaner-fuel-in-aviation-sector.

Graham, D., and K. Van Dender. 2009. "Estimating the Agglomeration Benefits of Transport Investments: Some Tests for Stability." Organisation for Economic Co-operation and Development, International Transport Forum. OECD/ITF Joint Transport Research Centre Discussion Papers 38 (January). doi:10.1007/s11116-010-9310-0.

Gulati, M., R. Becqué, N. Godfrey, A. Akhmouch, A. Cartwright, J. Eis, S. Huq, et al. 2020. The Economic Case for Greening the Global Recovery through Cities: Seven Priorities for National Governments. Washington, DC: Coalition for Urban Transitions, https://urbantransitions.global/wp-content/ uploads/2020/09/The_Economic_Case_for_Greening_the_Global_ Recovery_through_Cities_web_FINAL.pdf.

Hajat, A., C. Hsia, and M.S. O'Neill. 2015. "Socioeconomic Disparities and Air Pollution Exposure: A Global Review." Current Environmental Health Reports 2 (4): 440-50. doi:10.1007/s40572-015-0069-5.

Hall, D., and N. Lutsey. 2019. "Estimating the Infrastructure Needs and Costs for the Launch of Zero-Emission Trucks." White paper. Washington, DC: International Council on Clean Transportation.

Harsdorf, M., G. Montt, A. Rius, A. Bonnet, and T. Luu. 2020. Jobs in Green and Healthy Transport: Making the Green Shift. Geneva: International Labour Organization. https://wwwilo.org/global/publications/books/WCMS_745151/ lang--en/index.htm.

Hepburn, C., B. O'Callaghan, N. Stern, J. Stiglitz, and D. Zenghelis. 2020. "Will COVID-19 Fiscal Recovery Packages Accelerate or Retard Progress on Climate Change?" Oxford Review of Economic Policy 36 (Supplement_1): S359-81. doi:10.1093/oxrep/graa015.

Hepher, T. 2020. "France Bets on Green Plane in Package to 'Save' Aerospace Sector." Reuters, June 9. https://www.reuters.com/article/us-healthcoronavirus-france-aerospace-idUSKBN23G0TB.

The Hindu. 2020. "Kejriwal Announces Notification of Delhi Electric Vehicle Policy." August 7. https://www.thehindu.com/news/cities/Delhi/kejriwalannounces-notification-of-delhi-electric-vehicle-policy/article32293392.ece.

HVT (High Volume Transport). 2020. "Nigeria Paves the Way to Transport Recovery, but Sustainable Development Needs to Go Faster Say Experts." High Volume Transport (blog), October 15. http://transport-links.com/news/ nigeria-paves-the-way-to-transport-recovery-but-sustainable-developmentneeds-to-go-faster-say-experts/.

IATA (International Air Transport Association). 2020. "Five Years to Return to the Pre-pandemic Level of Passenger Demand." IATA Economics' Chart of the Week. https://wwwilata.org/en/iata-repository/publications/economicreports/Five-years-to-return-to-the-pre-pandemic-level-of-passengerdemand/.

ICA0 (International Civil Aviation Organization). 2017. "Sustainable Aviation Fuels Guide_090418." https://www.icao.int/environmental-protection/ knowledge-sharing/Docs/Sustainable Aviation Fuels Guide_vf.pdf.

ICA0. 2020. "Effects of Novel Coronavirus (COVID-19) on Civil Aviation: Economic Impact Analysis." Presented at the Air Transport Bureau, Montreal, December 17. https://www.icao.int/sustainability/Documents/COVID-19/ ICAO_Coronavirus_Econ_Impact.pdf.
ICCT (International Council on Clean Transportation). 2020. "Vision 2050: A Strategy to Decarbonize the Global Transport Sector by Mid-century." https:// theicct.org/sites/default/files/publications/ICCT_Vision2050_sept2020.pdf.

IEA (International Energy Agency). 2019a. "The Future of Hydrogen: Analysis." https://www.iea.org/reports/the-future-of-hydrogen.

IEA. 2019b. "The Future of Rail: Analysis." https://www.iea.org/reports/thefuture-of-rail.

IEA. 2020a. "Sustainable Recovery." https://www.iea.org/reports/ sustainable-recovery.

IEA. 2020b. "Global Energy and CO Emissions in 2020." https://www. iea.org/reports/global-energy-review-2020/global-energy-and-co2emissions-in-2020.

IFC (International Finance Corporation), 2021. A Green Reboot for Emerging Markets: Key Sectors for Post-COVID Sustainable Growth. Washington, DC: World Bank Group, https://www.ifc.org/wps/wcm/connect/26f79albc191-494b-b2d9-c891e138bb37/IFC_GreenReport_FINAL_web. pdf?MOD=AJPERES\&CVID=nrXRzUQ.

ILO (International Labour Organization). 2018. Women and Men in the Informal Economy: A Statistical Picture. 3rd ed. Geneva: IL0. http://www.lo.org/global/ publications/books/WCMS_626831/lang--en/index.htm.

IL0. 2020. "COVID-19 and Urban Passenger Transport Services." https:// www.ilo.org/wcmsp5/groups/public/---ed_dialogue/---sector/documents/ briefingnote/wcms_757023.pdf.

ILO. 2021. "ILO Monitor: COVID-19 and the World of Work." https://wwwilo.org/ wcmsp5/groups/public/---dgreports/---dcomm/documents/briefingnote/ wcms_767028.pdf.

IMF (International Monetary Fund)، 2021. "Fiscal Monitor Update, January 2021." https://www.imf.org/en/Publications/FM/Issues/2021/01/20/fiscalmonitor-update-january-2021.

Isaac, M., E. Griffith, and A. Satariano. 2020. "Uber Buys Postmates for $\$ 2.65$ Billion." New York Times, July 6. https://www.nytimes.com/2020/07/05/ technology/uber-postmates-deal.html.

ITF (International Transport Forum). 2019. "ITF Transport Outlook 2019." https://doi.org/10.1787/transp_outlook-en-2019-en.

ITF. 2020a. "COVID-19 Transport Brief: Re-spacing Our Cities for Resilience." https://www.itf-oecd.org/sites/default/files/respacing-cities-resiliencecovid-19.pdf.

ITF. 2020b. "Good to Go? Assessing the Environmental Performance of New Mobility." September. https://www.itf-oecd.org/good-go-assessingenvironmental-performance-new-mobility.

Jackson, E. 2020. "Do Hydrogen Fuel Cell Vehicles Make Sense for Cities?" TheCityFix (blog), August 19. https://thecityfix.com/blog/hydrogen-fuel-cellvehicles-make-sense-cities-eleanor-jackson/.

Jacques, K.S., and H.S. Levinson. 1997. Operational Analysis of Bus Lanes on Arterials. Transit Cooperative Research Program 26. Washington, DC: National Academy Press. 
Jaeger, J., K. McLaughlin, J. Neuberger, and C. Dellesky. 2021. "Does Biden's American Jobs Plan Stack Up on Climate and Jobs?" World Resources Institute (blog), April 1. https://www.wri.org/blog/2021/04/american-jobsplan-climate-jobs-us.

Jaeger, J., M.I. Westphal, and C. Park. 2020. "Lessons Learned on Green Stimulus: Case Studies from the Global Financial Crisis." Working paper. Washington, DC: World Resources Institute. https://www.wri.org/ publication/lessons-learned-on-green-stimulus-case-studies-from-theglobal-financial-crisis.

Jaramillo, A. 2020. "Bogotá Is Building Its Future around Bikes." Bloomberg CityLab, August 10, https://www.bloomberg.com/news/articles/2020-08-10/ to-tame-traffic-bogot-bets-big-on-bike-lanes.

Jennings, G. 2020. "Gaining or Losing Ground: Ensuring that Post-COVID-19 Transportation Serves the Needs of Women in Low-Income Sub-Saharan African Cities." High Volume Transport Applied Research Programme. https:// transport-links.com/download/gaining-or-losing-ground-ensuring-that-postcovid-19-transportation-serves-the-needs-of-women-in-low-income-subsaharan-african-cities/.

John, E. 2020. "Ochenuel Mobility." https://www.mobility.ochenuel.com.ng/ covid19/implications-for-transporation-in-abuja.

Kalia, R., and S. Maiti. 2021. "Rethinking Urban Freight Transport in Mumbai: A Paradigm Shift from Road to Rail." TheCityFix (blog), January 7. https:// thecityfix.com/blog/rethinking-urban-freight-transport-in-mumbai-aparadigm-shift-from-road-to-rail/,

Kane, J.W., and R. Puentes. 2015. "Expanding Opportunity through Infrastructure Jobs." Brookings Institution. https://www.brookings.edu/ research/expanding-opportunity-through-infrastructure-jobs/.

Kennedy, C., I.D. Stewart, and M.I. Westphal. 2019. "Shifting Currents: Opportunities for Low-Carbon Electric Cities in the Global South." Working paper. Washington, DC: World Resources Institute. https://www.wri.org/ publication/shifting-currents.

Kharwal, S., and A. Mukherjee. 2020. "Back to Business: Enabling Public Bus Systems post COVID-19." WRI India (blog), June 17, https://wri-india.org/blog/ back-business-enabling-public-bus-systems-post-covid-19.

Kothari, V., and R. Sclar. 2020. "4 Reasons to Prioritize Electric Vehicles after COVID-19." TheCityFix (blog), October 14. https://thecityfix.com/blog/4reasons-to-prioritize-electric-vehicles-after-covid-19/.

Lahcen, Bı, J. Brusselaers, K. Vrancken, Y. Dams, C. Da Silva Paes, J. Eyckmans, and S. Rousseau. 2020. "Green Recovery Policies for the COVID-19 Crisis: Modelling the Impact on the Economy and Greenhouse Gas Emissions." Environmental and Resource Economics 76 (4): 731-50. doi:10.1007/s10640020-00454-9.

Larsen, K., P.P. Chaudhuri, J.F. Kirkegaard, J. Larsen, L. Wright, A. Rivera, and H. Pitt. 2020. "It's Not Easy Being Green: Stimulus Spending in the World's Major Economies." Rhodium Group. https://rhg.com/research/green-stimulusspending/.

Lawrence, M., R. Bullock, and Z. Liu. 2019. China's High-Speed Rail Development. Washington, DC: World Bank. doi:10.1596/978-1-4648-1425-9.
Lebling, K., M. Ge, K. Levin, R. Waite, J. Friedrich, C. Elliott, C. Chan, et al. 2020. State of Climate Action: Assessing Progress toward 2030 and 2050. Washington, DC: World Resources Institute. https://www.wri.org/publication/ state-climate-action-assessing-progress-toward-2030-and-2050.

Lee, D.S., D.W. Fahey, A. Skowron, M.R. Allen, U. Burkhardt, Q. Chen, S.J. Doherty, et al. 2021. "The Contribution of Global Aviation to Anthropogenic Climate Forcing for 2000 to 2018." Atmospheric Environment 244 (January): 117834. doi:10.1016/j.atmosenv.2020.117834.

Lee, I.-M., E.J. Shiroma, F. Lobelo, P. Puska, S.N. Blair, and P.T. Katzmarzyk. 2012. "Effect of Physical Inactivity on Major Non-communicable Diseases Worldwide: An Analysis of Burden of Disease and Life Expectancy." Lancet 380 (9838): 219-29. doi:10.1016/S0140-6736(12)61031-9.

Lee, S. 2020. "How South Korea Is Managing Public Transportation under COVID-19." Moviliblog (blog), June 30. https://blogs.iadb.org/transporte/en/ how-south-korea-is-managing-public-transportation-under-covid-19/.

Leipziger, D., and B. Lefevre. 2015. "Private Investment in Public Transport: Success Stories from Brazilian Cities." World Resources Institute. https:// files.wri.org/s3fs-public/15_REP_0vercoming_Barriers-web.pdf.

Le Quéré, C., R.B. Jackson, M.W. Jones, A.J.P. Smith, S. Abernethy, R.M. Andrew, A.J. De-Gol, et al. 2020. "Temporary Reduction in Daily Global CO Emissions during the COVID-19 Forced Confinement." Nature Climate Change 10 (7): 647-53. doi:10.1038/s41558-020-0797-X.

Li, F., Y. Su, J. Xie, W. Zhu, and Y. Wang. 2020. "The Impact of High-Speed Rail Opening on City Economics along the Silk Road Economic Belt." Sustainability 12 (8): 3176. doi:10.3390/su12083176.

Li, H., J. Strauss, H. Shunxiang, and L. Lui. 2018. "Do High-Speed Railways Lead to Urban Economic Growth in China? A Panel Data Study of China's Cities." Quarterly Review of Economics and Finance 69 (August): 70-89. doi:10.1016/j.qref.2018.04.002.

Liu, D., L. Xue, and T. Huang, 2020a. "3 Ways China's Transport Sector Is Working to Recover from COVID-19 Lockdowns." TheCityFix (blog), April 30. https://thecityfix.com/blog/3-ways-chinas-transport-sector-workingrecover-covid-19-lockdowns/.

Liu, Z., P. Ciais, Z. Deng, R. Lei, S.J. Davis, S. Feng, B. Zheng, et al. 2020b. "NearReal-Time Monitoring of Global $\mathrm{CO}_{2}$ Emissions Reveals the Effects of the COVID-19 Pandemic." Nature Communications 11 (1): 5172. doi:10.1038/s41467020-18922-7.

López, A., A. Hoyos, F. Páez, A. Ramírez, D. Escalante, J.J. Hernández, A. Govea, et al. 2021. "Análisis de política para el diseño de un programa de apoyo estatal al transporte público urbano." WRI México.

Lucas, K., G. Mattioli, E. Verlinghieri, and A. Guzman. 2016. "Transport Poverty and Its Adverse Social Consequences." Transport 169 (March), doi:10.1680/ jtran.15.00073.

Mackett, R.L., and B. Brown. 2011. Transport, Physical Activity and Health: Present Knowledge and the Way Ahead. London: Centre for Transport Studies, University College London. http://www.cege.ucl.ac.uk/research/ projects?sq_content_src=\%2BdXJsPWhOdHAIM0EIMkYIMkZ3d3cyLmNIZ2UudWNsLmFjLnVrJTJGcmVzZWFyY2gIMkZSZXNQcm9qRGVOLmFzcCUzRkIE JTNEMTCOJmFsbDOx. 
Mahendra, A., and K.C. Seto. 2019. "Upward and Outward Growth: Managing Urban Expansion for More Equitable Cities in the Global South." Working paper. Washington, DC: World Resources Institute. https://www.wri.org/ wri-citiesforall/publication/upward-and-outward-growth-managing-urbanexpansion-more-equitable.

Mahler, D., C. Lanker, R.A.C. Aguilar, and H. Wu. 2020. "Updated Estimates of the Impact of COVID-19 on Global Poverty." World Bank. https://blogs.worldbank.org/opendata/updated-estimates-impact-covid-19-global-poverty.

Mallett, W. 2020. "Transportation Infrastructure Investment as Economic Stimulus: Lessons from the American Recovery and Reinvestment Act of 2009." Washington, DC: Congressional Research Service. https://fas.org/ sgp/crs/misc/R46343.pdf.

Mani, A., M. Pai, and R. Aggarwal. 2012. Sustainable Urban Transport in India. Washington, DC: World Resources Institute.

Manthey, N. 2021. "Dutch Municipalities to Set-Up Zero-Emission Zones by 2025." Electrive.Com (blog), February 15. https://www.electrive. com/2021/02/15/dutch-municipalities-to-set-up-zero-emission-zonesby-2025/.

Marcacci, S. 2019. "Renewable Energy Job Boom Creates Economic Opportunity as Coal Industry Slumps." Forbes, 2019. https://www.forbes.com/ sites/energyinnovation/2019/04/22/renewable-energy-job-boom-creatingeconomic-opportunity-as-coal-industry-slumps/.

Mason, J., L. Fulton, and Z. McDonald. 2015. "A Global High Shift Cycling Scenario." Institute for Transportation and Development Policy, https://www. itdp.org/2015/11/12/a-global-high-shift-cycling-scenario/.

McCarthy, N. 2020. "Infographic: How Covid-19 Boosted Cycling Investment in Europe." Statista Infographics, October 2. https://www.statista.com/ chart/23095/dditional-funding-allocated-for-cycling-during-the-pandemic/.

Meyer, S. 2020. "Understanding the COVID-19 Effect on Online Shopping Behavior." BigCommerce Blog, March 20. https://www.bigcommerce.com/ blog/covid-19-ecommerce/.

Mitterling, T., N. Tomass, and K. Wu. 2020. "The Decline and Recovery of Consumer Spending in the US." Brookings Institution, December 14, https:// www.brookings.edu/blog/future-development/2020/12/14/the-decline-andrecovery-of-consumer-spending-in-the-us/.

Mock, $P_{1}$, and Z. Yang. 2014. Driving Electrification: A Global Comparison of Fiscal Incentive Policy for Electric Vehicles. Washington, DC: International Council on Clean Transportation. https://theicct.org/sites/default/files/ publications/ICCT_EV-fiscal-incentives_20140506.pdf.

Moss, M.L., and H. O'Neill. 2020. Economic Consequences of Proposed Pandemic-Related Cutbacks in MTA Transportation Services and Capital Spending. New York: New York University Rudin Center for Transportation \& Appleseed.

New York Times. 2020. "Coronavirus World Map: Tracking the Global Outbreak." December 17. https://www.nytimes.com/interactive/2020/world/ coronavirus-maps.html.

NUMO (New Urban Mobility Alliance). 2020. "COVID Mobility Works." https:// www.covidmobilityworks.org/.
OECD (Organisation for Economic Co-operation and Development). 2020a. "Policy Brief: Making the Green Recovery Work for Jobs, Income and Growth." https://read.oecd-ilibrary.org/view/?ref=136_136201ctwt8p7qs5\&title=Making-the-Green-Recovery-Work-for-Jobs-Income-andGrowth_.

OECD. 2020b. "Cities Policy Responses." https://read.oecd-ilibrary.org/ view/?ref=126_126769-yen45847kf\&title=Coronavirus-COVID-19-CitiesPolicy-Responses.

OECD. 2021), Gross domestic product (GDP) (indicator), doi: 10.1787/ dc2f7aec-en.

PedBikelnfo (Pedestrian and Bicycle Information Center). 2020. "'Shifting Streets' Covid-19 Mobility Dataset." http://pedbikeinfo.org/resources/ resources_details.cfm?id=5235.

Pidcock, R., and S. Yeo, 2016. "Analysis: Aviation Could Consume a Quarter of 1.5C Carbon Budget by 2050." Carbon Brief, August 8. https://www. carbonbrief.org/aviation-consume-quarter-carbon-budget.

Pinheiro, B., C. Genin, R. Feltran-Barbieri, and V. Romeiro. 2020. "A New Economy for a New Era: Elements for Building a More Efficient and Resilient Economy in Brazil." WRI Brasil. https://wribrasil.org.br/pt/publicacoes/neweconomy-brazil-efficient-resilient-build-back-better.

Pratt, G.C., M.L. Vadali, D.L. Kvale, and K.M. Ellickson. 2015. "Traffic, Air Pollution, Minority and Socio-economic Status: Addressing Inequities in Exposure and Risk." International Journal of Environmental Research and Public Health 12 (5): 5355-72. doi:10.3390/ijerph120505355.

Rajé, $F_{1}$ and A. Saffrey. 2016. "The Value of Cycling." University of Birmingham. http://www.niagaraknowledgeexchange.com/wp-content/uploads/ sites/2/2016/04/value-of-cycling.pdf.

Reid, C. 2020. "Paris to Create 650 Kilometers of Post-lockdown Cycleways." Forbes, April 22. https://www.forbes.com/sites/carltonreid/2020/04/22/ paris-to-create-650-kilometers-of-pop-up-corona-cycleways-for-postlockdown-travel/.

Robins, N., R. Clover, and C. Singh. 2009. "A Climate for Recovery: The Colour of Stimulus Goes Green." HSBC. https://www.globaldashboard.org/wpcontent/uploads/2009/HSBC_Green_New_Deal.pdf.

Roth, G. 2020. "Siqueira Campos Exclusive Bus Lane Goes into Operation." Porto Alegre City Hall, August 14. https://prefeitura.poa.br/eptc/noticias/ faixa-exclusiva-da-siqueira-campos-entra-em-operacao.

Rott, N., and J. Ludden. 2020. "Trump Administration Weakens Auto Emissions Standards." National Public Radio, March 31. https://www.npr. org/2020/03/31/824431240/trump-administration-weakens-auto-emissionsrolling-back-key-climate-policy.

RV0 (Netherlands Enterprise Agency). 2019. "Mission Zero Powered by Holland." https://www.rvo.nl/sites/default/files/2019/06/Misson\%20Zero\%20 Powered\%20by\%20Holland.pdf.

SBTi (Science Based Targets initiative). 2021. "Companies Taking Action." https://sciencebasedtargets.org/companies-taking-action. 
Schwartz, J., L. Andres, and G. Dragoiu. 2009. "Crisis in Latin America: Infrastructure Investment, Employment and the Expectations of Stimulus." Policy research working paper. Washington, DC: World Bank. http://documents1. worldbank.org/curated/en/760281468054542825/pdf/WPS5009.pdf.

Schwedhelm, A., W. Li, L. Harms, and C. Adriazola-Steil. 2020. "Biking Provides a Critical Lifeline during the Coronavirus Crisis." World Resources Institute (blog), April 17. https://www.wri.org/blog/2020/04/coronavirus-bikingcritical-in-cities.

Seo, Y., and J. Berlinger. 2020. "In the Age of Coronavirus, These New Seoul Bus Shelters Refuse Entry to Anyone with a Fever." CNN, August 13, https:// www.cnn.com/travel/article/seoul-smart-shelters-covid-intl-hnk-scli/index. html.

Shalal, A. 2021. "IMF, World Bank to Unveil 'Green Debt Swaps' Option by November, Georgieva Says." Reuters, April 8. https://www.reuters.com/ article/us-imf-world-bank-climate-swaps-idUSKBN2BV2NU.

Shan, Y., J. Ou, D. Wang, Z. Zeng, S. Zhang, D. Guan, and K. Hubacek. 2021. "Impacts of COVID-19 and Fiscal Stimuli on Global Emissions and the Paris Agreement." Nature Climate Change 11 (3): 200-206. doi:10.1038/s41558-02000977-5.

Shankar, A., and T. Avni. 2020. A Fiscally Responsible Green Stimulus. New Delhi: The Energy and Resources Institute. https://www.teriin.org/sites/ default/files/2020-08/green-stimulus-dp.pdf.

Shannon, J., and R. Abadie. 2021. "Green Recovery: The Power of Innovative Partnerships." PricewaterhouseCoopers (blog), February 8. https://www. pwc.com/gx/en/issues/reinventing-the-future/take-on-tomorrow/greenrecovery.html.

Shin, $H_{\text {., }}$ and S. Cha. 2020. "South Korea to Spend $\$ 95$ Billion on Green Projects to Boost Economy." Reuters, July 14. https://www.reuters.com/ article/us-southkorea-president-newdeal-idUSKCN24F0GA.

Sims, R, R. Schaeffer, F. Creutzig, X. Cruz-Núñez, M. D’Agosto, D. Dimitriu, M.J.F. Meza, et al. 2014. "Transport." In Climate Change 2014: Mitigation of Climate Change. Contribution of Working Group III to the Fifth Assessment Report of the Intergovernmental Panel on Climate Change, ed. E. Deakin and S.K. Ribeiro. Cambridge: Cambridge University Press. https://www.academia. edu/20562696/Transport_In_Climate_Change_2014_Mitigation_of_ Climate_Change_Contribution_of_Working_Group_III_to_the_Fifth_ Assessment_Report_of_the_Intergovernmental_Panel_on_Climate_ Change.

SLOCAT (Partnership on Sustainable, Low Carbon Transport). 2018. Transport and Climate Change 2018: Global Status Report. Brussels: SLOCAT. https:// slocat.net/tcc-gsr/.

Smart Growth America. 2011. "Recent Lessons from the Stimulus: Transportation Funding and Job Creation." https://smartgrowthamerica.org/ app/legacy/documents/lessons-from-the-stimulus.pdf.

Smit, S., M. Hirt, K. Buehler, S. Lund, E. Greenberg, and A. Govindarajan. 2020. "Safeguarding Our Lives and Our Livelihoods: The Imperative of Our Time." McKinsey \& Company, https://www.mckinsey.com/business-functions/ strategy-and-corporate-finance/our-insights/safeguarding-our-lives-andour-livelihoods-the-imperative-of-our-time.
Smith, C. 2019. "An Overview of Current and Historical Funding from the Public and Private Sector." Washington, DC: Atlas Public Policy, https://www. atlasevhub.com/wp-content/uploads/2020/02/Investment-in-Public-EVCharging-in-the-United-States.pdf.

Sung, J., and Y. Monschauer. 2020. "Changes in Transport Behaviour during the Covid-19 Crisis: Analysis." International Energy Agency. https://wwwiea. org/articles/changes-in-transport-behaviour-during-the-covid-19-crisis.

Tanenbaum, M. 2020. "Philly Sees Boom in Cyclists, 471\% Increase on Kelly Drive Trail during Coronavirus Restrictions." PhillyVoice, March 20. https:// www.phillyvoice.com/philly-cycling-coronavirus-kelly-drive-trail-covid-19bicycle-coalition-covid-19/.

Tang, F. 2020. "Full Steam Ahead for China's Rail Network, despite Debt Concerns." South China Morning Post, January 21. https://www.scmp.com/ economy/china-economy/article/3046870/chinas-high-speed-railwaynetwork-advances-full-steam-ahead.

TDA (Transport Decarbonisation Alliance). 2018. "Decarbonising Transport by 2050." http://tda-mobility.org/wp-content/uploads/2018/12/EY_TDAManifesto.pdf.

Teachout, M., and C. Zipfel. 2020. "The Economic Impact of COVID-19 Lockdowns in Sub-Saharan Africa." International Growth Centre. https:// www.theigc.org/wp-content/uploads/2020/05/Teachout-and-Zipfel-2020policy-brief-.pdf.

Thaku, P., S. Pal, and S. Prakash. 2020. "COVID-19 Lockdown: Impacts on the Auto-Rickshaw Community." Energy Resource Institute (blog), July 29. https://www.teriin.org/article/covid-19-lockdown-impacts-auto-rickshawcommunity.

Transport for London. 2019. TfL Annual Report and Statement of Accounts, 2018/19. London: Transport for London. http://content.tfl.gov.uk/tfl-annualreport-and-statement-of-accounts-2018-19.pdf.

TUMI (Transformative Urban Mobility Initiative). 2021. "Major Automobile Manufacturers Have Announced Exits from the Internal Combustion Engine Market." Tweet, February 10. https://twitter.com/TUMInitiative/ status/1359490396167036934.

UITP (International Association of Public Transport). 2020. "Impact of COVID-19 on Indian Bus 0perators." Statistics brief. https://indd.adobe.com/ view/d6dd8493-bfe6-473a-8823-667d66420dc6.

UK Department for Transport. 2018. The Road to Zero: Next Steps towards Cleaner Road Transport and Delivering Our Industrial Strategy, London: HM Government. https://assets.publishing.service.gov.uk/government/uploads/ system/uploads/attachment_data/file/739460/road-to-zero.pdf.

UK Department for Transport. 2020. "£2 Billion Package to Create New Era for Cycling and Walking." May 9. https://www.gov.uk/government/news/2billion-package-to-create-new-era-for-cycling-and-walking.

UNEP (UN Environment Programme). 2016. "Global Outlook on Walking and Cycling." https://wedocs.unep.org/bitstream/handle/20.500.11822/17030/ globalOutlookOnWalkingAndCycling.pdf.

UNEP. 2019. Emissions Gap Report, 2019. Nairobi: UNEP. http://www. unenvironment.org/resources/emissions-gap-report-2019. 
UNEP. 2020. "African Green Stimulus Programme." Draft. https://wedocs. unep.org/xmlui/handle/20.500.11822/34409.

UNFCCC (UN Framework Convention on Climate Change). 2020. "NAZCA Global Climate Action." https://climateaction.unfccc.int/.

UNICEF (UN Children's Fund). 2020، "COVID-19 and School Closures: Are Children Able to Continue Learning?" https://data.uniceforg/resources/ remote-learning-reachability-factsheet/.

Vanier, C., and L. Isaac. 2020. "France to Inject Almost \$9 Billion into Ailing Auto Industry." CNN, May 26. https://www.cnn.com/2020/05/26/business/ france-auto-industry-bailout/index.html.

Venter, C., A. Mahendra, and D. Hidalgo. 2019. "From Mobility to Access for All: Expanding Urban Transportation Choices in the Global South." Working paper. Washington, DC: World Resources Institute. https://www.wri.org/wricitiesforall/publication/mobility-access-all-expanding-urban-transportationchoices-global-south.

Vivid Economics. 2021. "Green Stimulus Index." https://www.vivideconomics. com/wp-content/uploads/2020/08/200820-GreenStimulusIndex_web.pdf.

Wallbox. 2020. "Everything You Need to Know about EV Incentives in the Netherlands." Wallbox (blog), June 25. https://blog.wallbox.com/en/ netherlands-ev-incentives/.

Walton, N., and H. Jonker. 2020. "Germany's COVID-19 Stimulus Prioritizes Low-Carbon Investments." World Resources Institute (blog), July 2. https:// www.wri.org/blog/2020/07/germany-s-covid-19-stimulus-prioritizes-lowcarbon-investments.

Wanek-Libman, M. 2020. "Where Transit Stands with COVID-19 Relief Bill and FY21 Omnibus Legislation." Mass Transit, December. https://www. masstransitmag.com/management/article/21203606/where-transit-standswith-covid19-relief-bill-and-fy21-omnibus-legislation.

Warren, H. 2020، "Coronavirus Travel: London Commuters Swap Trains for Bikes." Bloomberg (blog), June 10. https://www.bloomberg.com/ graphics/2020-london-cycling-streetspace/.

Waskow, D., T. Fransen, and J. Jaeger. 2020. "NDC Enhancement and COVID-19 Recovery: Building Blocks for a Sustainable Future." World Resources Institute (blog), September 23. https://www.wri.org/news/ndcenhancement-and-covid-19-recovery-building-blocks-sustainable-future.

Watts, J. 2020. "People Plan to Drive More Post-Covid, Climate Poll Shows." Guardian, November 10. https://www.theguardian.com/environment/2020/ nov/10/people-drive-fly-climate-crisis-global-poll-green-recovery-covidpandemic

WEF (World Economic Forum), 2020. "The Future of the Last-Mile Ecosystem." http://www3.weforum.org/docs/WEF_Future_of_the_last_mile_ ecosystem.pdf.

Welle, B. 2020. "COVID-19 Has Reshuffled Public Space: Buses Deserve a Greater Share." TheCityFix (blog), July 16. https://thecityfix.com/blog/covid19-reshuffled-public-space-buses-deserve-greater-share-ben-welle/.
Welle, B., A.B. Sharpin, C. Adriazola-Steil, S. Alveano, M. Obelheiro, C.T. Imamoglu, S. Job, et al. 2018. Sustainable and Safe: A Vision and Guidance for Zero Road Deaths. Washington, DC: World Resources Institute. https://www. wri.org/publication/sustainable-and-safe-vision-and-guidance-zero-roaddeaths.

Welle, B., and S. Avelleda. 2020. "Invest in Public Transport after COVID-19." TheCityFix (blog), April 23. https://thecityfix.com/blog/coronavirus-publictransport-stimulus-packages-ben-welle-sergio-avelleda/.

Wheatley, J. 2021. "IMF Prepares to Bolster Developing Countries' Finances." Financial Times, April 5. https://www.ft.com/content/50bbaa46-2b30-4d35bb36-804bc82b068f.

WHO (World Health Organization). 2018, "Global Status Report on Road Safety 2018." https://apps.who.int/iris/bitstream/handle/10665/277370/WHO-NMHNVI-18.20-eng.pdf?ua=1.

WH0. 2019, "Ambient Air Pollution." https://www.who.int/teams/environmentclimate-change-and-health/air-quality-and-health/ambient-air-pollution.

Wilson, K. 2020. "Federal Corona Bill Seems Generous to Transit. It's Not." Streetsblog USA, April 8. https://usa.streetsblog.org/2020/04/08/federalcorona-relief-bill-seems-generous-to-transit-its-not/.

World Bank. 2017. "The High Toll of Traffic Injuries: Unacceptable and Preventable." http://hdl.handle.net/10986/29129.

World Bank. 2020a. "COVID-19 and Public Transport in Africa." https://www. ssatp.org/sites/ssatp/files/publication/COVID19\%20and\%20Public\%20 Transport\%20in\%20Africa\%20-\%20FINAL\%20-\%20Aug2020\%20-\%20 ENGLISH.pdf.

World Bank. 2020b. "Railway PPPs." Public-Private Partnership Legal Resource Center, December. https://ppp.worldbank.org/public-privatepartnership/sector/transportation/railway-trains.

WRI (World Resources Institute), 2020. "Climate Action Tracker." https:// climateactiontracker.org/.

Xin, Z. 2020، "China Doubling High-Speed Rail Network to Help Steady Economic Growth." South China Morning Post, August 14. https://www.scmp. com/economy/china-economy/article/3097226/china-high-speed-railwaynetwork-double-length-2035-under.

Yeon-j00, K., and K. Hyo-jin. 2020. "Korea to Extend Subsidies for Electric Cars to 2025 to Support Green New Deal." Pulse, August 7. https://pulsenews, co.kr/view.php?year=2020\&no=733375.

Zhang, X., J. Xie, R. Rao, and Y. Liang. 2014. "Policy Incentives for the Adoption of Electric Vehicles across Countries." Sustainability 6 (11): 8056-78. doi:10.3390/su6118056.

Zhao, X., A. Mahendra, N. Godfrey, H. Dalkmann, P. Rode, and G. Floater. 2016. "Unlocking the Power of Urban Transport Systems for Better Growth and a Better Climate." Coalition for Urban Transitions, January 1. https:// urbantransitions.global/en/publication/unlocking-the-power-of-urbantransport-systems-for-better-growth-and-a-better-climate/.

Zipper, D. 2021. "E-Bikes for Everyone!" Slate Magazine, February 25. https:// slate.com/technology/2021/02/e-bikes-act-electric-bicycles-subsidy.html. 


\section{ACKNOWLEDGMENTS}

We are pleased to acknowledge our institutional strategic partners that provide core funding to WRI: the Netherlands Ministry of Foreign Affairs, Royal Danish Ministry of Foreign Affairs, and Swedish International Development Cooperation Agency.

This paper was supported by the Transport Decarbonisation Alliance (TDA) and its chair, Stientje van Veldhoven, minister for the environment, government of the Netherlands. We give special thanks to the TDA and its members for feedback throughout the development of this paper. A special thanks to Herman Sips of the Netherlands Ministry of Infrastructure and Water Management and the TDA for shepherding the paper from its genesis to publication.

We would like to thank those who offered comments on the paper or process., including Nicolas Beaumont, Claire Marie Bernard, Maruxa Cardama, Clarisse Durand, Mark Major, Hans Verdonk, and Patrick Oliva. We are additionally grateful for the support of our WRI reviewers, Claudia Adriazola-Steil, Sebastian Castellanos, Thiago Guimarães, Joel Jaeger, Ravi Ponnapureddy, Ryan Sclar, and Thet Hein Tun. We give another thank you to WRI's Research, Data, \& Innovation team, Robin King, Anjali Mahendra, Emily Matthews, and Laura Valeri, whose knowledge elevated our paper to loftier heights. We also thank WRI Ross Center for Sustainable Cities Global Director Ani Dasgupta for his critical feedback and guidance. Finally, we are grateful for the editorial, communications, administrative, and design support of Alex Martin, Gabriela Mora, Emilia Suarez, Shannon Collins, and Romain Warnault-without your support this paper would not have been possible.
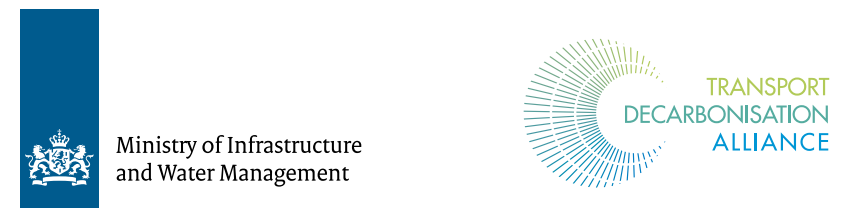

\section{ABOUT THE AUTHORS}

Travis Fried was a Research Analyst with the WRI Ross Center for Sustainable Cities.

Benjamin Welle is Director of Integrated Transport and Innovation at the WRI Ross Center for Sustainable Cities.

Sergio Avelleda is Senior Advisor, Urban Mobility, at the WRI Ross Center for Sustainable Cities.

\section{ABOUTWRI}

World Resources Institute is a global research organization that turns big ideas into action at the nexus of environment, economic opportunity, and human well-being.

\section{Our Challenge}

Natural resources are at the foundation of economic opportunity and human well-being. But today, we are depleting Earth's resources at rates that are not sustainable, endangering economies and people's lives. People depend on clean water, fertile land, healthy forests, and a stable climate. Livable cities and clean energy are essential for a sustainable planet. We must address these urgent, global challenges this decade.

\section{Our Vision}

We envision an equitable and prosperous planet driven by the wise management of natural resources. We aspire to create a world where the actions of government, business, and communities combine to eliminate poverty and sustain the natural environment for all people.

\section{Our Approach}

COUNT IT

We start with data. We conduct independent research and draw on the latest technology to develop new insights and recommendations. Our rigorous analysis identifies risks, unveils opportunities, and informs smart strategies. We focus our efforts on influential and emerging economies where the future of sustainability will be determined.

\section{CHANGE IT}

We use our research to influence government policies, business strategies, and civil society action. We test projects with communities, companies, and government agencies to build a strong evidence base. Then, we work with partners to deliver change on the ground that alleviates poverty and strengthens society. We hold ourselves accountable to ensure our outcomes will be bold and enduring.

\section{SCALE IT}

We don't think small. Once tested, we work with partners to adopt and expand our efforts regionally and globally. We engage with decision-makers to carry out our ideas and elevate our impact. We measure success through government and business actions that improve people's lives and sustain a healthy environment.

c) creative Copyright 2021 World Resources Institute. This work is licensed under the Creative Commons Attribution 4.0 International License.

To view a copy of the license, visit http://creativecommons.org/licenses/by/4.0/ 